\title{
Phosphonium cation-based ionic liquids as neat lubricants: physicochemical and tribological performance
}

\author{
A. Hernández Battez ${ }^{\mathrm{a}, \mathrm{d}^{*}}$, M. Bartoloméb ${ }^{\mathrm{b}}$ D. Blanco ${ }^{\mathrm{a}}$, J.L. Viesca ${ }^{\mathrm{a}, \mathrm{d}}$ \\ A. Fernández-González ${ }^{\mathrm{C}}$, R. González ${ }^{\mathrm{b}, \mathrm{d}}$ \\ ${ }^{\text {a }}$ Department of Construction and Manufacturing Engineering, University of Oviedo, Asturias, Spain \\ ${ }^{(*)}$ Email: aehernandez@uniovi.es \\ ${ }^{\mathrm{b}}$ Department of Marine Science and Technology, University of Oviedo, Asturias, Spain \\ ${ }^{\mathrm{c}}$ Department of Physical and Analytical Chemistry, University of Oviedo, Asturias, Spain \\ ${ }^{\mathrm{d}}$ Faculty of Science \& Technology, Bournemouth University, UK
}

\begin{abstract}
This paper studies physicochemical properties (density, viscosity, corrosion, thermogravimetry, and conductivity) and tribological behavior of five phosphonium cation-based ionic liquids ([ $\left.\mathrm{P}_{66614}\right][\mathrm{BEHP}]$, $\left[\mathrm{P}_{66614}\right]\left[\mathrm{C}_{8} \mathrm{C}_{8} \mathrm{PO}_{2}\right],\left[\mathrm{P}_{66614}\right]\left[\mathrm{NTf}_{2}\right],\left[\mathrm{P}_{44414}\right][\mathrm{DBS}]$, and $\left.\left[\mathrm{P}_{4442}\right][\mathrm{DEP}]\right)$ as neat lubricants within steel-steel contact. A reciprocating ball-on-disc configuration was used to perform tribological tests. Worn surfaces were analyzed by confocal microscopy, SEM, EDS and XPS. Main results showed that: $\left[\mathrm{P}_{66614}\right]\left[\mathrm{NTf}_{2}\right]$, $\left[\mathrm{P}_{44414}\right][\mathrm{DBS}]$, and [ $\left.\mathrm{P}_{4442}\right][\mathrm{DEP}]$ showed corrosion activity; the ionic liquids with more reactive phosphate type anion $\left(\left[\mathrm{P}_{66614}\right][\mathrm{BEHP}]\right.$ and $\left.\left[\mathrm{P}_{4442}\right][\mathrm{DEP}]\right)$ had the best tribological behavior; the best tribological results were related to the tribofilm formation of two phosphate species.
\end{abstract}

Keywords: phosphonium ionic liquids, physicochemical properties, friction, wear

\section{Introduction}

In the 1970s and 1980s, ionic liquids (ILs) began to be used in a wide variety of applications, mostly as "customizable" solvents or electrolytes in batteries [1-2]. Generally, this kind of salts has nonflammability, low volatility, low combustibility, high ionic conductivity, high thermo-oxidative stability and miscibility with organic compounds [3]. Over the last 15 years, research interest in ILs has expanded into lubrication due to their potential performance as neat lubricant or additive [4-11]. Early works were focused on ILs with imidazolium cations and fluorine-containing anions [12-16]. However, the hydrolysis products of those anions are highly corrosive and toxic, making those ILs only applicable to water-free conditions [17].

The great lubricating performance of ILs is directly related to their capacity to form adsorbed films on the metal surface, mostly due to their high polarity [18-21] and reactivity under high loads [5]. These facts contribute to the friction and wear reduction properties of ILs [22]. Regarding the use of ILs as neat lubricants, several studies have shown great potential for this purpose [16, 20, 23-28]. However, the replacement of traditional base oils by ILs is currently limited by their cost, so their use as neat lubricant has been evaluated for special conditions (diesel engine, vacuum and MEMS applications) [29-31]. 
The interest in phosphonium based ILs has widely grown over the years in line with their increased commercial availability. They have been tested for several applications such as extraction solvents, chemical synthesis solvents, electrolytes in batteries and super-capacitors, and in corrosion protection [32]. From a tribological point of view, some ILs of this family have been tested as neat lubricants reporting better tribological performance than imidazolium counterparts [33-35] and conventional oils [22, 36-37]. Table 1 summarizes the main works developed with phosphonium cation-based ionic liquids in tribology.

Table 1. Phosphonium cation-based ionic liquids used as neat lubricants.

\begin{tabular}{|c|c|c|c|}
\hline $\begin{array}{l}\text { Phosphonium Based } \\
\text { Ionic Liquids }\end{array}$ & $\begin{array}{c}\text { Contact } \\
\text { Materials }\end{array}$ & Tribological tests & References \\
\hline $\begin{array}{c}{\left[\mathrm{P}_{66614}\right]\left[\left(\mathrm{C}_{2} \mathrm{~F}_{5}\right)_{3} \mathrm{PF}_{3}\right]} \\
{\left[\mathrm{P}_{4442}\right]\left[\mathrm{C}_{2} \mathrm{C}_{2} \mathrm{PO}_{4}\right]}\end{array}$ & $\begin{array}{l}\text { 100Cr6 Steel balls } \\
\text { AISI } 420 \text { stainless } \\
\text { steel plates }\end{array}$ & $\begin{array}{l}\text { Reciprocating } \\
\text { Ball on Plate }\end{array}$ & [20] \\
\hline $\begin{array}{c}{\left[\mathrm{P}_{2225}\right]\left[\mathrm{NTf}_{2}\right],\left[\mathrm{P}_{2228}\right]\left[\mathrm{NTf}_{2}\right]} \\
{\left[\mathrm{P}_{22212}\right]\left[\mathrm{NTf}_{2}\right],} \\
{\left[\left(\mathrm{C}_{2} \mathrm{H}_{5}\right)_{3} \mathrm{C}_{2} \mathrm{H}_{4} \mathrm{OCH}_{3} \mathrm{P}\right]\left[\mathrm{NTf}_{2}\right]} \\
{\left[\left(\mathrm{C}_{2} \mathrm{H}_{5}\right)_{3} \mathrm{CH}_{2} \mathrm{C}_{6} \mathrm{H}_{5} \mathrm{P}\right]\left[\mathrm{NTf}_{2}\right]} \\
{\left[\mathrm{P}_{4442}\right]\left[\mathrm{NTf}_{2}\right],\left[\mathrm{P}_{4448}\right]\left[\mathrm{NTf}_{2}\right]} \\
{\left[\mathrm{P}_{88812}\right]\left[\mathrm{NTf}_{2}\right],\left[\mathrm{P}_{4441}\right][\mathrm{DMP}]} \\
{\left[\mathrm{P}_{4444}\right]\left[\left(\mathrm{C}_{2} \mathrm{H}_{5} \mathrm{O}\right)_{2} \mathrm{PSS}\right]}\end{array}$ & $\begin{array}{l}\text { SUJ2 (JIS) Steel } \\
\text { balls } \\
\text { SUJ2 (JIS) Steel } \\
\text { Flats }\end{array}$ & $\begin{array}{l}\text { Reciprocating } \\
\text { Ball on Flat }\end{array}$ & [33] \\
\hline $\begin{array}{c}{\left[\mathrm{P}_{66614}\right][\mathrm{BEHP}],} \\
{\left[\mathrm{P}_{66614}\right]\left[(\mathrm{iC})_{2} \mathrm{PO}_{2}\right],\left[\mathrm{P}_{66614}\right][\mathrm{SSi}],} \\
{\left[\mathrm{P}_{66614}\right][\mathrm{DPP}],\left[\mathrm{P}_{66614}\right]\left[\mathrm{NTf}_{2}\right],} \\
{\left[\mathrm{P}_{66614}\right]\left[\left(\mathrm{C}_{2} \mathrm{~F}_{5}\right)_{3} \mathrm{PF}_{3}\right],\left[\mathrm{P}_{1444}\right][\mathrm{DPP}]}\end{array}$ & $\begin{array}{l}\text { 100Cr6 Steel balls } \\
\text { Aluminum } \\
\text { AA2024 disks }\end{array}$ & Pin on Disk & [38-39] \\
\hline
\end{tabular}

Otero et al. [20] studied the use of two phosphonium cation-based ionic liquids: $\left[\mathrm{P}_{66614}\right]\left[\left(\mathrm{C}_{2} \mathrm{~F}_{5}\right)_{3} \mathrm{PF}_{3}\right]$ and $\left[\mathrm{P}_{4442}\right]\left[\mathrm{C}_{2} \mathrm{C}_{2} \mathrm{PO}_{4}\right]$ as neat lubricants to steel-steel contact. Tribological tests were conducted at room temperature under loads of 14, 18, 22 and $26 \mathrm{~N}$ (corresponding to maximum pressures of 1.6 to 1.96 GPa), frequency of $3.2 \mathrm{~Hz}$, speed of $0.1 \mathrm{~m} / \mathrm{s}$, and a sliding distance of $100 \mathrm{~m}$. $\left[\mathrm{P}_{4442}\right]\left[\mathrm{C}_{2} \mathrm{C}_{2} \mathrm{PO}_{4}\right]$ showed the best antifriction ability but its wear reduction behavior and thermal stability were worse than the $\left[\mathrm{P}_{66614}\right]\left[\left(\mathrm{C}_{2} \mathrm{~F}_{5}\right)_{3} \mathrm{PF}_{3}\right]$ ones. The XPS analyses revealed that both ionic liquids formed tribofilms on the worn surface mainly composed by iron phosphides and oxides.

Minami et al. [33] worked with 10 phosphonium based ionic liquids: $\left[\mathrm{P}_{2225}\right]\left[\mathrm{NTf}_{2}\right]$, $\left[\mathrm{P}_{2228}\right]\left[\mathrm{NTf}_{2}\right]$, $\left[\mathrm{P}_{22212}\right]\left[\mathrm{NTf}_{2}\right], \quad\left[\left(\mathrm{C}_{2} \mathrm{H}_{5}\right)_{3} \mathrm{C}_{2} \mathrm{H}_{4} \mathrm{OCH}_{3} \mathrm{P}\right]\left[\mathrm{NTf}_{2}\right], \quad\left[\left(\mathrm{C}_{2} \mathrm{H}_{5}\right)_{3} \mathrm{CH}_{2} \mathrm{C}_{6} \mathrm{H}_{5} \mathrm{P}\right]\left[\mathrm{NTf}_{2}\right], \quad\left[\mathrm{P}_{4442}\right]\left[\mathrm{NTf}_{2}\right], \quad\left[\mathrm{P}_{4448}\right]\left[\mathrm{NTf}_{2}\right]$, $\left[\mathrm{P}_{88812}\right]\left[\mathrm{NTf}_{2}\right],\left[\mathrm{P}_{4441}\right][\mathrm{DMP}]$ and $\left[\mathrm{P}_{4444}\right]\left[\left(\mathrm{C}_{2} \mathrm{H}_{5} \mathrm{O}\right)_{2} \mathrm{PSS}\right]$ using a T-type pendulum friction tester and a ballon-flat-type tribometer in reciprocating configuration in order to study friction and wear properties of the samples. They found a mixture of phosphate and fluoride boundary films due to tribochemical reactions 
occurring at the surface during a low-load tribotest, being the fluoride film predominant under these conditions. The tribological properties of phosphate anion-based ionic liquids were way better than the $\left[\mathrm{NTf}_{2}\right]$ anion-based ones, mostly due to a lubrication mechanism based on the formation of a phosphate boundary film similar to that provoked by ZDDP.

Somers et al. [38] studied the use of 7 phosphonium cation-based ionic liquids: $\left[\mathrm{P}_{66614}\right][\mathrm{BEHP}]$, $\left[\mathrm{P}_{66614}\right]\left[(\mathrm{iC} 8)_{2} \mathrm{PO}_{2}\right],\left[\mathrm{P}_{66614}\right][\mathrm{SSi}],\left[\mathrm{P}_{66614}\right][\mathrm{DPP}],\left[\mathrm{P}_{66614}\right]\left[\mathrm{NTf} \mathrm{f}_{2}\right],\left[\mathrm{P}_{66614}\right][\mathrm{FAP}]$ and $\left[\mathrm{P}_{1444}\right][\mathrm{DPP}]$ as neat lubricants for the lubrication of steel-aluminium contacts. In order to get appreciable wear, ionic liquids were tested under a pin-on-disk configuration at $40 \mathrm{~N}$ of load, $0.1 \mathrm{~m} / \mathrm{s}$ of velocity, and sliding distance of $1000 \mathrm{~m}$. The results demonstrated a strong influence of the anion on the friction and wear values. Besides, Somers et al. [39] also studied 9 ionic liquids, including 4 of the above mentioned phosphonium cationbased ionic liquids: $\left[\mathrm{P}_{66614}\right]\left[\mathrm{NTf}_{2}\right],\left[\mathrm{P}_{66614}\right][\mathrm{FAP}],\left[\mathrm{P}_{66614}\right][\mathrm{DPP}]$ and $\left[\mathrm{P}_{1444}\right][\mathrm{DPP}]$, under a pin-on-disk configuration but using loads of $1,2,5,10,20$ and $40 \mathrm{~N}$ (corresponding with initial mean contact pressures of 0.29 to $0.98 \mathrm{GPa}$ ) for a sliding distance of $1000 \mathrm{~m}$ and speed of $0.2 \mathrm{~m} / \mathrm{s}$. As in previous work [38], two of the best wear protecting ILs were $\left[\mathrm{P}_{66614}\right]\left[\mathrm{NTf}_{2}\right]$ and $\left[\mathrm{P}_{66614}\right][\mathrm{DPP}]$, pointing out that the charge localization and alkyl chain length of the cation are critical in achieving maximum wear protection. The XPS analyses demonstrated that the increase in pressure and temperature leads to breakdown of the IL species and the reaction of these products with the fresh metal surface. For the case of the $\left[\mathrm{NTf}_{2}\right]$ anion the possibility of tribocorrosion was exposed.

In order to broaden the knowledge about using phosphonium cation-based ionic liquids as neat lubricants, this work explores the physicochemical properties and tribological performance of five liquids ([P $\left.\mathrm{P}_{66614}\right][\mathrm{BEHP}],\left[\mathrm{P}_{66614}\right]\left[\mathrm{C}_{8} \mathrm{C}_{8} \mathrm{PO}_{2}\right],\left[\mathrm{P}_{66614}\right]\left[\mathrm{NTf}_{2}\right],\left[\mathrm{P}_{44414}\right][\mathrm{DBS}]$, and $\left.\left[\mathrm{P}_{4442}\right][\mathrm{DEP}]\right)$ applied to steel-steel contacts, in order to assess the feasibility of using them in the way that they are commercially available.

\section{Experimental details}

\subsection{Ionic liquids}

Five phosphonium cation-based ionic liquids: $\left[\mathrm{P}_{66614}\right]\left[(\mathrm{iC} 8)_{2} \mathrm{PO}_{2}\right], \quad\left[\mathrm{P}_{66614}\right][\mathrm{BEHP}], \quad\left[\mathrm{P}_{66614}\right]\left[\mathrm{NTf}_{2}\right]$, $\left[\mathrm{P}_{44414}\right][\mathrm{DBS}]$, and $\left[\mathrm{P}_{4442}\right][\mathrm{DEP}]$, used as neat lubricants in this work were provided by Ionic Liquid Technologies GmbH (Io-Li-Tec). Table 2 shows the chemical description of the ionic liquids. 
Table 2. Ionic liquids.

\begin{tabular}{|c|c|c|c|c|}
\hline \multicolumn{5}{|c|}{ Ionic Liquids } \\
\hline Chemical structure & IUPAC name & $\begin{array}{l}\text { Purity } \\
(\%)\end{array}$ & $\begin{array}{l}\text { Molecular } \\
\text { Weight }\end{array}$ & $\begin{array}{l}\text { Empirical } \\
\text { Formula }\end{array}$ \\
\hline & $\begin{array}{c}\text { Trihexyltetradecylphosphonium } \\
\text { bis(2,4,4-trimethylpentyl) } \\
\text { phosphinate } \\
{\left[\mathrm{P}_{66614}\right]\left[(\mathrm{iC} 8)_{2} \mathrm{PO}_{2}\right]}\end{array}$ & 95 & 773.27 & $\mathrm{C}_{48} \mathrm{H}_{102} \mathrm{O}_{2} \mathrm{P}_{2}$ \\
\hline & $\begin{array}{c}\text { Trihexyltetradecylphosphonium } \\
\text { bis(2-ethylhexyl)phosphate } \\
\qquad\left[\mathrm{P}_{66614}\right][\mathrm{BEHP}]\end{array}$ & 98 & 805.29 & $\mathrm{C}_{48} \mathrm{H}_{102} \mathrm{O}_{4} \mathrm{P}_{2}$ \\
\hline & $\begin{array}{c}\text { Trihexyltetradecylphosphonium } \\
\text { bis(trifluoromethylsulfonyl) } \\
\text { imide } \\
{\left[\mathrm{P}_{66614}\right]\left[\mathrm{NTf}_{2}\right]}\end{array}$ & 98 & 764.01 & $\mathrm{C}_{34} \mathrm{H}_{68} \mathrm{~F}_{6} \mathrm{NO}_{4} \mathrm{PS}_{2}$ \\
\hline & $\begin{array}{c}\text { Tributyltetradecylphosphonium } \\
\text { dodecylbenzenesulfonate } \\
{\left[\mathrm{P}_{44414}\right][\mathrm{DBS}]}\end{array}$ & 95 & 725.18 & $\mathrm{C}_{44} \mathrm{H}_{85} \mathrm{O}_{3} \mathrm{PS}$ \\
\hline & $\begin{array}{c}\text { Tributylethylphosphonium } \\
\text { Diethylphosphate } \\
{\left[\mathrm{P}_{4442}\right][\mathrm{DEP}]}\end{array}$ & 95 & 384.47 & $\mathrm{C}_{18} \mathrm{H}_{42} \mathrm{O}_{4} \mathrm{P}_{2}$ \\
\hline
\end{tabular}

\subsection{Physicochemical properties}

Infrared spectra of the ionic liquids were taken in a Varian 670-IR FTIR spectrometer (Australia) equipped with a Golden Gate horizontal attenuated total reflectance (ATR) accessory. The spectrometer was completely software-controlled by the Varian Resolutions Prosoftware provided by Varian Inc. Experimental conditions were 16 scans, $4 \mathrm{~cm}^{-1}$ resolution, aperture open. Spectra were recorded between 600 and $4000 \mathrm{~cm}^{-1}$. 
Density and dynamic viscosity of the ionic liquids were measured at atmospheric pressure according to ASTM D7042 in a range of 10 to $100^{\circ} \mathrm{C}$ using a rotational Couette viscometer (Stabinger SVM3000), which also includes a vibrating tube density meter. From these results, the apparatus automatically calculates the kinematic viscosity and provides the viscosity index (VI) according to the ASTM D2270-04.

Despite the well-known high thermal stability of the ionic liquids, thermogravimetric analyses (TGA) of the five ionic liquids were made on a Mettler Toledo TGA/SDTA851 to determine the decomposition temperatures. Dynamic scans were carried out from room temperature to approximately $600^{\circ} \mathrm{C}$ at a heating rate of $10^{\circ} \mathrm{C} / \mathrm{min}$ under oxygen and nitrogen atmospheres with a flow rate of $50 \mathrm{ml} / \mathrm{min}$ in both cases.

Corrosion character of the ILs was studied using a simple test: applying separately all the ionic liquids studied on the surface of an AISI 52100 steel disc (previously ultrasonically cleaned in heptane and air dried) which remained at room temperature for 20 days while the corrosion activity was observed. Subsequently, the steel surfaces were analyzed by scanning electron microscopy (SEM) and energy dispersive spectroscopy (EDS).

Moreover, the conductivities of the ionic liquids were also measured in a temperature range $25-42^{\circ} \mathrm{C}$ by a model HI 9835 EC-TDS conductivity meter made by Hanna Instruments.

\subsection{Tribological tests}

A microprocessor-controlled Bruker UMT-3 tribometer with a reciprocating ball-on-disc configuration was used to perform the tribological tests. 60-min tests were conducted under a load of $40 \mathrm{~N}$ (corresponding to a maximum contact pressure of $1.67 \mathrm{GPa}$ ), $15 \mathrm{~Hz}$ of frequency and stroke length of $4 \mathrm{~mm}$. Tribological tests were conducted at room temperature with a relative humidity in the range 20-30\%, and using $25 \mu \mathrm{L}$ of the corresponding ionic liquid inside the contact. Friction coefficient was recorded during the test and wear depth on the discs was measured after tests using a Leica DCM 3D confocal microscope.

The upper specimen used was AISI 52100 chrome steel balls (0.98-1.1\% C; 0.15-0.30\% Si; 0.25-0.45\% Mn; 1.30-1.60\% Cr; $0.025 \%$ P; $0.025 \%$ S) with $9.5 \mathrm{~mm}$ diameter, hardness of 63 HRC and approximately $0.01 \mu \mathrm{m}$ of surface finish (Ra). The lower specimen was AISI 52100 steel discs (machined from annealed rod) with a hardness of $190-210 \mathrm{HV}_{30}$ and less than $0.02 \mu \mathrm{m}$ of surface finish (Ra). Both 
specimens were cleaned before tribological tests with heptane in an ultrasonic bath for 5 minutes, rinsed in ethanol and dried with hot air. The lubricant samples were tested at least three times under each test condition and the specimens were also cleaned with heptane, rinsed in ethanol and dried with hot air after tribological tests and before surface characterization.

\subsection{Surface characterization}

Scanning electron microscopy (SEM), energy dispersive spectroscopy (EDS) and X-Ray photoelectron spectroscopy (XPS) were also employed to analyze and evaluate the interaction of the ionic liquids with the worn surface.

SEM-EDS analysis was made using an acceleration voltage of $20 \mathrm{kV}$. Additionally, XPS measurements were performed using a Phoibos 150 with a monochromatized $\mathrm{x}$-ray source $(\mathrm{Ka} \mathrm{Al}=1486.74 \mathrm{eV})$ at $13 \mathrm{kV}$ and $300 \mathrm{~W}$. The energy analyzer worked on constant pass energy mode. Survey spectra were performed using $90 \mathrm{eV}$ pass energy and $1 \mathrm{eV}$ step energy and high-resolution spectra were taken with $30 \mathrm{eV}$ pass energy and $0.1 \mathrm{eV}$ step energy. Spatial resolution was achieved combining a small X-ray spot size $\left(3.5 \times 1 \mathrm{~mm}^{2}\right)$ with the electromagnetic lenses working in small area mode. Charge shift was compensated with a flood electron gun when necessary. Depth-profiling was carried out using an Argon plasma gun at $3000 \mathrm{eV}$ energy; each layer was etched by a plasma scan in a $4 \times 4 \mathrm{~mm}^{2}$ area. Position of spurious C1s indicated that it is not necessary to correct the energy shift due to charge effects. Shirleytype base lines and 70\% Gaussian-30\% Lorentizan curves were used for all mathematical fittings, carried out in Casa XPS software using Marquardt-Levenberg or Simplex methods [41].

\section{Results and discussion}

\subsection{Physicochemical properties}

Each ionic liquid showed absorptions at $2855 \mathrm{~cm}^{-1}, 2925 \mathrm{~cm}^{-1}$ and $2950 \mathrm{~cm}^{-1}$ rising from the $-\mathrm{CH}_{2}$ - bonds of the long aliphatic chains present in all of them (Fig. 1). The ionic liquids $\left[\mathrm{P}_{66614}\right]\left[(\mathrm{iC} 8)_{2} \mathrm{PO}_{2}\right]$, $\left[\mathrm{P}_{66614}\right][\mathrm{BEHP}]$ and $\left[\mathrm{P}_{4442}\right][\mathrm{DEP}]$ show a single band between $1350 \mathrm{~cm}^{-1}$ and $1150 \mathrm{~cm}^{-1}$ assignable to $\mathrm{P}=\mathrm{O}$ bond. However, $\left[\mathrm{P}_{66614}\right]\left[(\mathrm{iC} 8)_{2} \mathrm{PO}_{2}\right]$ has the band at lower frequency $\left(1170 \mathrm{~cm}^{-1}\right)$ than $\left[\mathrm{P}_{66614}\right][\mathrm{BEHP}]$ and $\left[\mathrm{P}_{4442}\right][\mathrm{DEP}]$ (both at $1245 \mathrm{~cm}^{-1}$ ). This difference is due to the different groups bonded to the $\mathrm{P}=\mathrm{O}$ group, as $\left[\mathrm{P}_{66614}\right][\mathrm{BEHP}]$ and $\left[\mathrm{P}_{4442}\right][\mathrm{DEP}]$ have two -OR groups that are more electronegative than the carbon chains bonded in $\left[\mathrm{P}_{66614}\right]\left[(\mathrm{iC} 8)_{2} \mathrm{PO}_{2}\right]$. 

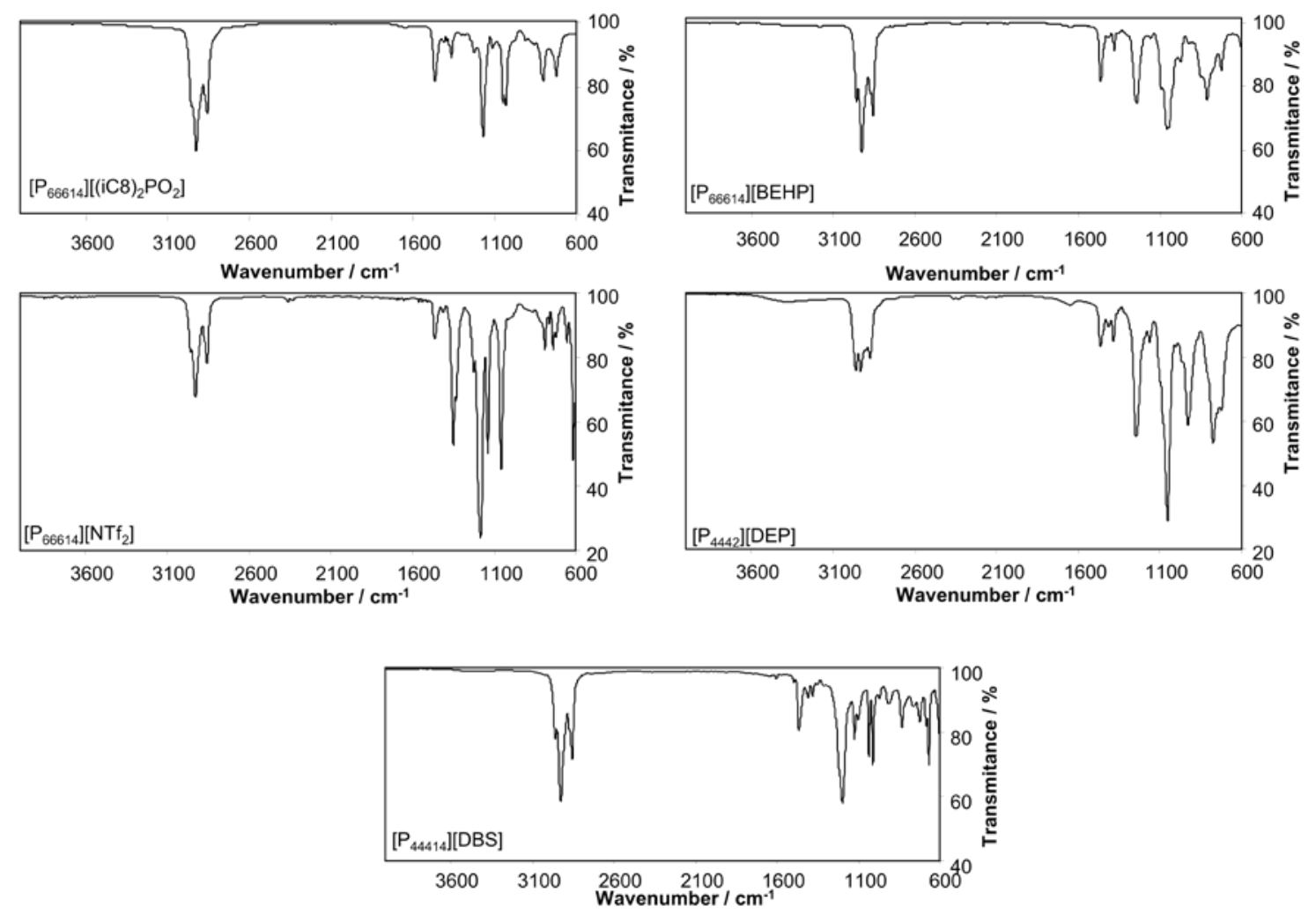

Fig. 1. FTIR measurements of the ionic liquids.

On the other hand, $\left[\mathrm{P}_{66614}\right]\left[\mathrm{NTf}_{2}\right]$ presents six identical bands at $1055 \mathrm{~cm}^{-1}$ (a), $1135 \mathrm{~cm}^{-1}$ (b), $1180 \mathrm{~cm}^{-1}$ (c), $1225 \mathrm{~cm}^{-1}$ (d), $1330 \mathrm{~cm}^{-1}$ (e) and $1348 \mathrm{~cm}^{-1}$ (f) which must come from the bis(trifluoromethylsulfonyl)imide anion which is not present in the other ionic liquids. These can be demonstrated taking into account that $\mathrm{CF}_{3}-$ stretching appears between $1215 \mathrm{~cm}^{-1}$ and $1175 \mathrm{~cm}^{-1}$ (probably band $d$ slightly shifted; similar anions like trifluoromethanesulfonate present absorbance at $1224 \mathrm{~cm}^{-1}$ [42]), asymmetric $\mathrm{SO}_{2}$ stretching is between $1380 \mathrm{~cm}^{-1}$ and $1325 \mathrm{~cm}^{-1}$ (bands e and f) and symmetric stretching between $1170 \mathrm{~cm}^{-1}$ and $1150 \mathrm{~cm}^{-1}$ (probably band $c$ slightly shifted) [43]. Additionally, a broad intense band has been reported for the sodium salt of the dodecylbenzenesulfonate at $1198 \mathrm{~cm}^{-1}$ which can also be detected at $1195 \mathrm{~cm}^{-1}$ in $\left[\mathrm{P}_{44414}\right]$ [DBS] [42]. Similarly, the sodium salt shows two peaks of about similar intensity at $1042 \mathrm{~cm}^{-1}$ and $1012 \mathrm{~cm}^{-1}$, also present in $\left[\mathrm{P}_{44414}\right][\mathrm{DBS}]$ at $1010 \mathrm{~cm}^{-1}$ and $1035 \mathrm{~cm}^{-1}$. Furthermore, the peak at $835 \mathrm{~cm}^{-1}$ is probably related to the presence of 4 hydrogen atoms in the benzene rings in positions 2, 3, 5 and 6 as described by Socrates [43]. 
Figure 2 represents the density of the phosphonium cation-based ILs between 10 and $100^{\circ} \mathrm{C}$. The values are between 1.079 and $0.893 \mathrm{~g} / \mathrm{cm}^{3}$ at $10^{\circ} \mathrm{C}$ and between 1.014 and $0.840 \mathrm{~g} / \mathrm{cm}^{3}$ at $100^{\circ} \mathrm{C}$, decreasing linearly with temperature rise as expected. $\left[\mathrm{P}_{66614}\right]\left[(\mathrm{iC} 8)_{2} \mathrm{PO}_{2}\right]$ and $\left[\mathrm{P}_{66614}\right][\mathrm{BEHP}]$ presented the lowest density values due to the presence of higher alkyl chain lengths [18], followed by $\left[\mathrm{P}_{44414}\right][\mathrm{DBS}]$ and $\left[\mathrm{P}_{4442}\right][\mathrm{DEP}]$. On the other hand, $\left[\mathrm{P}_{66614}\right]\left[\mathrm{NTf}_{2}\right]$ showed a singular high value although it shares the same cation with the two ionic liquids with lower values, suggesting that the effect of the anion is more important in this case [44].

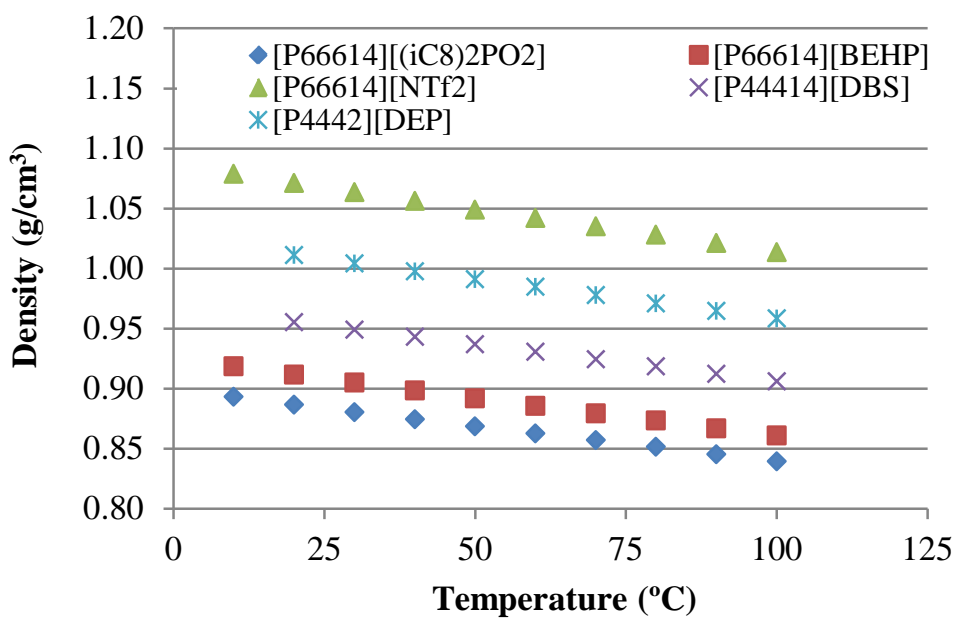

Fig. 2. Density-temperature behavior of the phosphonium cation-based ionic liquids.

The viscosity index (VI) and viscosity (dynamic and kinematic) at three temperatures (25, 40 and $\left.100{ }^{\circ} \mathrm{C}\right)$ for the phosphonium based ILs are summarized in Table 3. The viscosity difference of the ionic liquids becomes smaller as the temperature rises due to the different viscosity indexes of the samples. If the interaction energy of a cation-anion pair increases, ion bonding is stronger and leads to a higher viscosity [45]. Besides, the number of carbons per chain as well as the symmetry and size of the ions cause increased resistance to shear flow and consequently higher viscosity. Moreover, the results indicate that the high hydrogen bonding and interaction energy of $\left[\mathrm{P}_{44414}\right][\mathrm{DBS}]$ weights more than the smaller size of these ions compared with $\left[\mathrm{P}_{66614}\right]\left[(\mathrm{iC} 8)_{2} \mathrm{PO}_{2}\right]$ and $\left[\mathrm{P}_{66614}\right][\mathrm{BEHP}]$. The same explanation can be attributed to $\left[\mathrm{P}_{4442}\right][\mathrm{DEP}]$ versus $\left[\mathrm{P}_{66614}\right]\left[\mathrm{NTf}_{2}\right]$, with the second one being less viscous.

With regard to viscosity index $(\mathrm{VI})$, the values for the five ILs increase in this order: $\left[\mathrm{P}_{4442}\right][\mathrm{DEP}]<$ $\left[\mathrm{P}_{44414}\right][\mathrm{DBS}]<\left[\mathrm{P}_{66614}\right]\left[\mathrm{NTf}_{2}\right]<\left[\mathrm{P}_{66614}\right]\left[(\mathrm{iC} 8)_{2} \mathrm{PO}_{2}\right]<\left[\mathrm{P}_{66614}\right][\mathrm{BEHP}]$. The low VI for $\left[\mathrm{P}_{44414}\right][\mathrm{DBS}]$ could be attributed to the presence of a cyclic group, which decrease this property [20]. Besides, the viscosity 
index generally seems to be related to the IL's molecular weight but is little affected by the cation symmetry [18].

Table 3. Viscosity of the ionic liquids.

\begin{tabular}{|c|c|c|c|c|c|c|c|}
\hline \multirow{3}{*}{ Ionic liquids } & \multicolumn{6}{|c|}{ Temperature } & \multirow{3}{*}{ IV } \\
\hline & \multicolumn{2}{|c|}{$25^{\circ} \mathrm{C}$} & \multicolumn{2}{|c|}{$40^{\circ} \mathrm{C}$} & \multicolumn{2}{|c|}{$100^{\circ} \mathrm{C}$} & \\
\hline & $v(\mathrm{mPa} \cdot \mathrm{s})$ & $\eta\left(\mathrm{mm}^{2} / \mathrm{s}\right)$ & $v(\mathrm{mPa} \cdot \mathrm{s})$ & $\eta\left(\mathrm{mm}^{2} / \mathrm{s}\right)$ & $v(\mathrm{mPa} \cdot \mathrm{s})$ & $\eta\left(\mathrm{mm}^{2} / \mathrm{s}\right)$ & \\
\hline$\left[\mathrm{P}_{66614}\right]\left[(\mathrm{iC} 8)_{2} \mathrm{PO}_{2}\right]$ & 1064 & 1204.1 & 462.51 & 528.93 & 46.23 & 55.06 & 169 \\
\hline$\left[\mathrm{P}_{66614}\right][$ BEHP $]$ & 1050 & 1156 & 474.35 & 528.05 & 50.80 & 59.00 & 181 \\
\hline$\left[\mathrm{P}_{66614}\right]\left[\mathrm{NTf}_{2}\right]$ & 295.91 & 277.26 & 130.45 & 123.49 & 16.37 & 16.15 & 140 \\
\hline$\left[\mathrm{P}_{44414}\right][\mathrm{DBS}]$ & 4212 & 4423.1 & 1278 & 1355.2 & 56.48 & 62.34 & 98 \\
\hline$\left[\mathrm{P}_{4442}\right][\mathrm{DEP}]$ & 454.83 & 451.39 & 171.45 & 171.53 & 14.20 & 14.81 & 83 \\
\hline
\end{tabular}

Thermal stability tests of the ILs were made to determine its thermal decomposition temperature, although it is not simple. Using a single technique such as TGA, there are many factors that come into play (presence of humidity, impurities, sample size, heating rate...) making difficult the comparison of data from different sources [46]. This issue strongly affects the accuracy of temperature measurements like temperature of onset of thermal degradation $\left(\mathrm{T}_{\text {onset }}\right)$ and maximum-rate degradation $\left(\mathrm{T}_{\max }\right)$, both shown in Table 4 and obtained from Figs. 3a-4a and Figs. 3b-4b, respectively. It is well known that the thermal stability of the ILs is strongly anion dependent [47-49]. Previous works [47-48] suggest that the $\left[\mathrm{NTf}_{2}\right]$ anion confers high thermal stability and single step degradation to the ILs, being consistent with the results obtained in this study (Figs. $3-4)$. On the other hand, $\left[\mathrm{P}_{66614}\right][\mathrm{BEHP}]$ and $\left[\mathrm{P}_{4442}\right][\mathrm{DEP}]$ displayed two steps degradation, possibly due to the influence of a more reactive phosphate type anion [49]. Also early weight losses are due to the impurities (between 2-5\% in weight according with Table 2) present in the ionic liquids used in this study [46].

Table 4. Degradation temperatures of the ionic liquids under oxygen and nitrogen atmospheres.

\begin{tabular}{|c|c|c|c|c|}
\hline \multirow{3}{*}{ Ionic Liquids } & \multicolumn{4}{|c|}{ Atmosphere } \\
\hline & \multicolumn{2}{|c|}{$\mathrm{O}_{2}(50 \mathrm{ml} / \mathrm{min})$} & \multicolumn{2}{|c|}{$\mathrm{N}_{2}(50 \mathrm{ml} / \mathrm{min})$} \\
\hline & $\mathrm{T}_{\text {onset }}\left({ }^{\circ} \mathrm{C}\right)$ & $\mathrm{T}_{\max }\left({ }^{\circ} \mathrm{C}\right)$ & $\mathrm{T}_{\text {onset }}\left({ }^{\circ} \mathrm{C}\right)$ & $T_{\max }\left({ }^{\circ} \mathrm{C}\right)$ \\
\hline$\left[\mathrm{P}_{66614}\right]\left[(\mathrm{iC} 8)_{2} \mathrm{PO}_{2}\right]$ & 248.46 & 310.1 & 300.73 & 374 \\
\hline$\left[\mathrm{P}_{66614}\right][\mathrm{BEHP}]$ & 247.76 & 307.5 & 293.48 & 329.7 \\
\hline$\left[\mathrm{P}_{66614}\right]\left[\mathrm{NTf}_{2}\right]$ & 349.44 & 446.8 & 417.30 & 453.2 \\
\hline$\left[\mathrm{P}_{44414}\right][\mathrm{DBS}]$ & 284.99 & 345.5 & 333.01 & 450 \\
\hline$\left[\mathrm{P}_{4442}\right][\mathrm{DEP}]$ & 239.03 & 284.7 & 304.10 & 523 \\
\hline
\end{tabular}



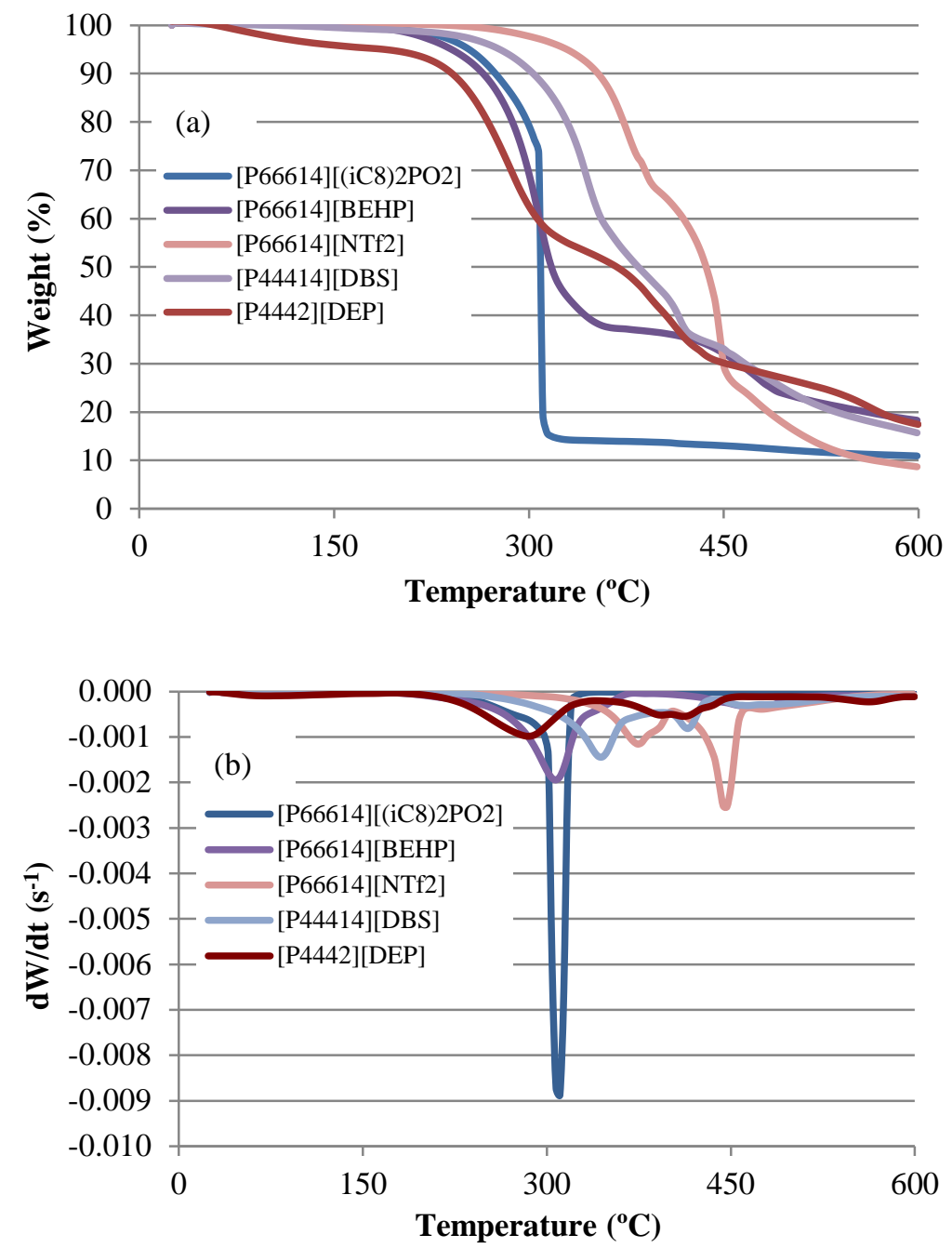

Fig. 3. Thermal analysis of the ionic liquids under $\mathrm{O}_{2}$ atmosphere: (a) thermogravimetric curves (b) differential thermogravimetric curves.

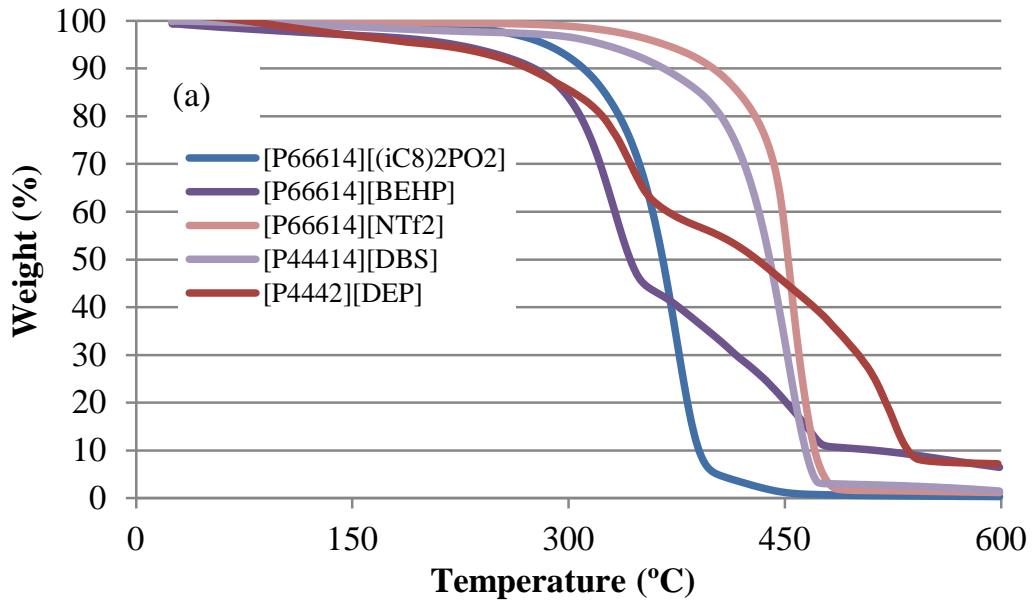




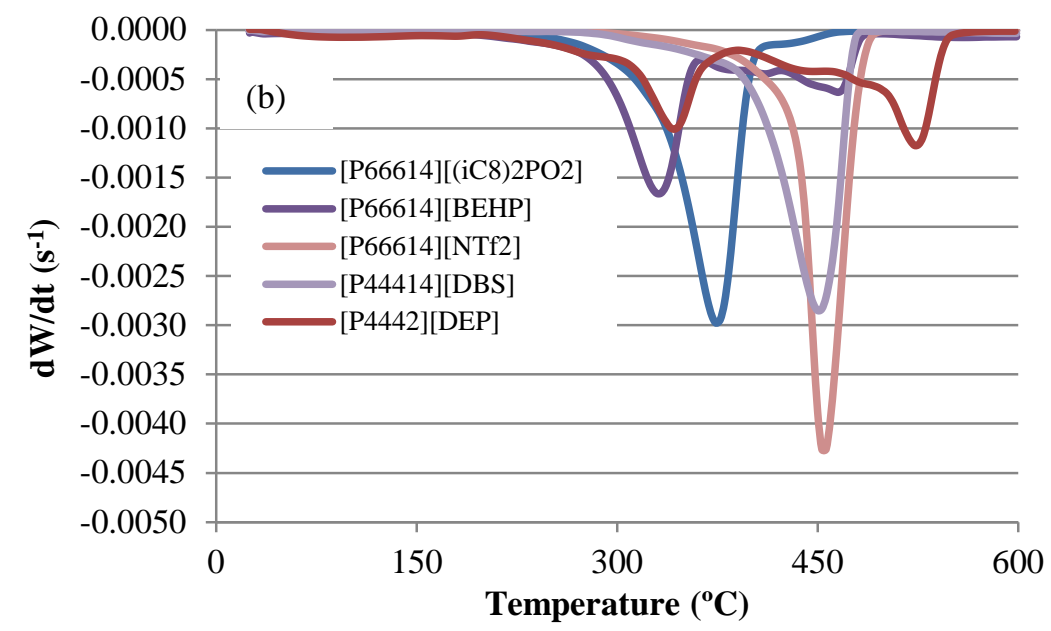

Fig. 4. Thermal analysis of the ionic liquids under $\mathrm{N}_{2}$ atmosphere: (a) thermogravimetric curves

(b) differential thermogravimetric curves.

Corrosion tests were carried out to determine the effect of the five ionic liquids on the surface of AISI 52100 steel discs. SEM observations of the first sample (Fig. 5) showed no alteration on the surface after 20 days exposed to $\left[\mathrm{P}_{66614}\right]\left[(\mathrm{iC} 8)_{2} \mathrm{PO}_{2}\right]$; while EDS analysis showed almost exclusively the elements of the steel (Fe, C, $\mathrm{Cr}$ ) at three different positions on the specimen surface.
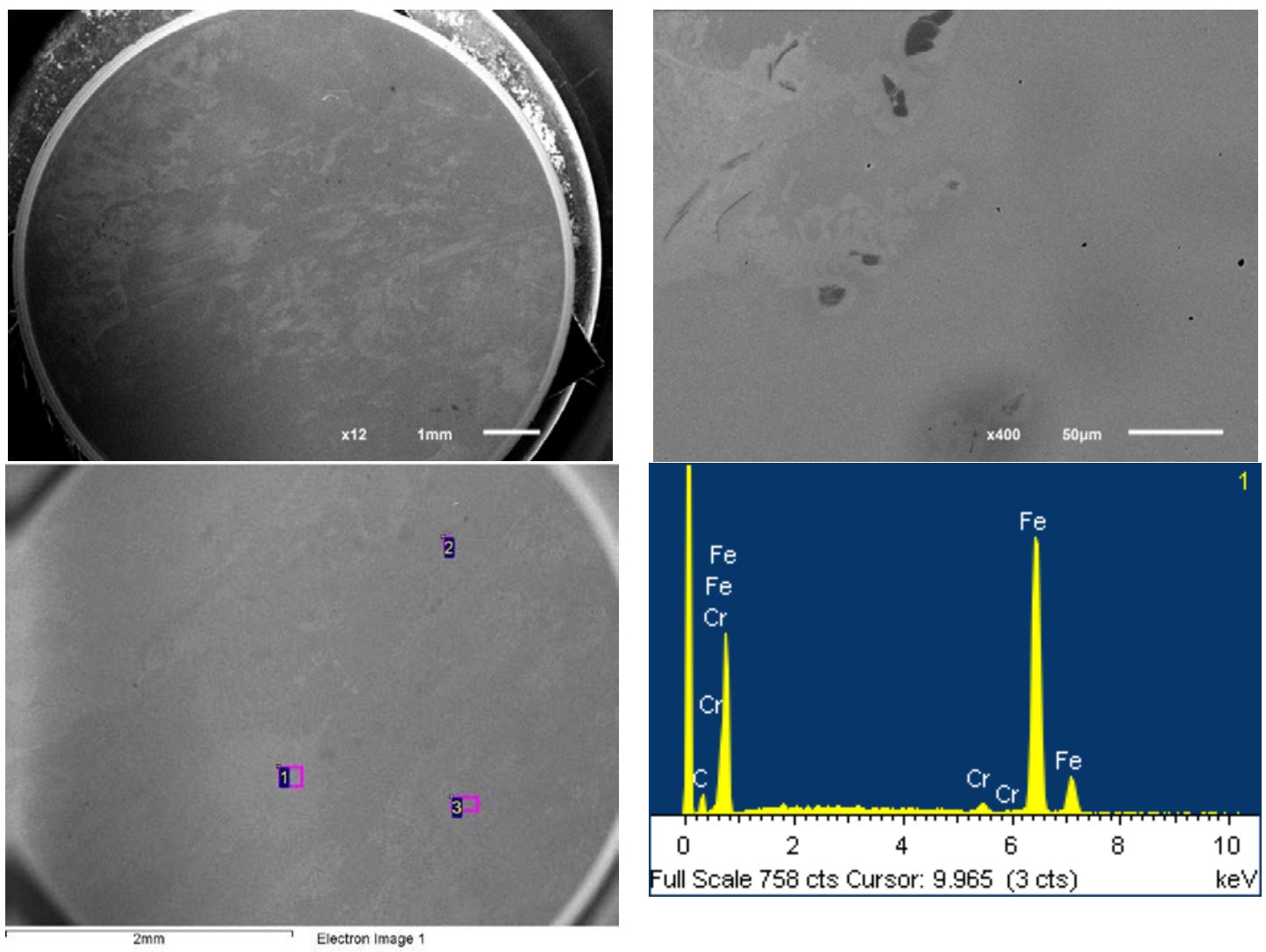

Full Scale 758 cts Cursor: 9.965 (3 cts) 

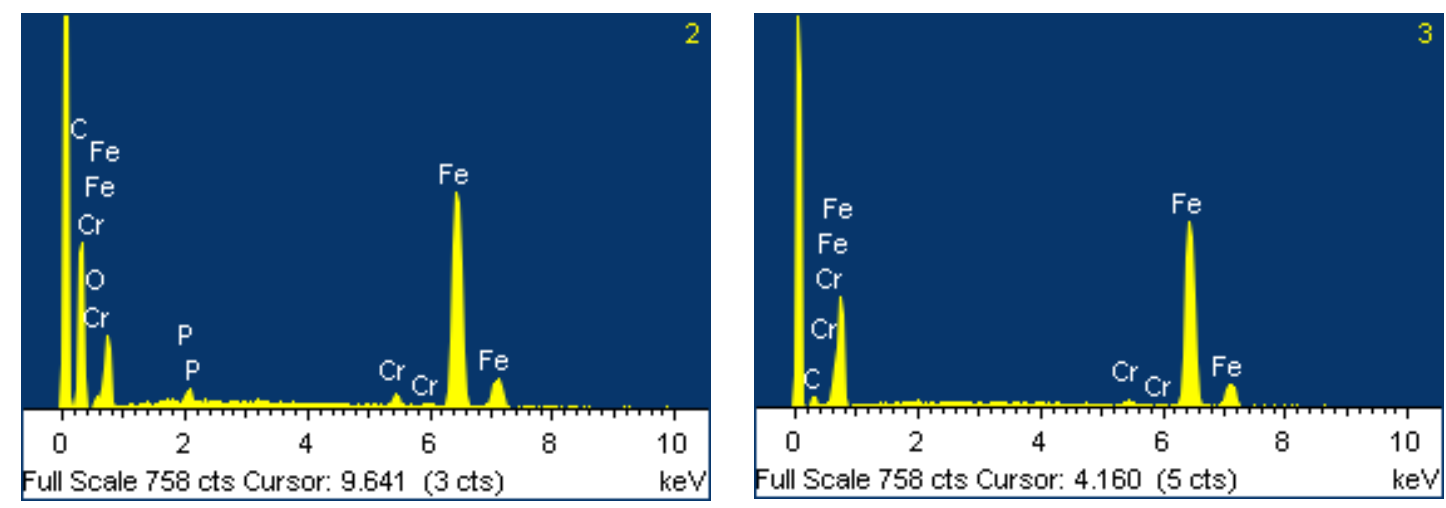

Fig. 5. SEM micrographs (x12 and x400) and EDS spectra of the AISI 52100 steel disc surface wetted with $\left[\mathrm{P}_{66614}\right]\left[(\mathrm{iC} 8)_{2} \mathrm{PO}_{2}\right]$.

Similar to the corrosion test with $\left[\mathrm{P}_{66614}\right]\left[(\mathrm{iC} 8)_{2} \mathrm{PO}_{2}\right]$, SEM micrographs of the disc surface wetted with $\left[\mathrm{P}_{66614}\right][\mathrm{BEHP}]$ (Fig. 6) also exhibited no corrosion or alterations on the steel surface 20 days after the interaction with the ionic liquid and therefore EDS analysis showed almost identical results identifying the elements present in the steel (Fe, C, Cr).
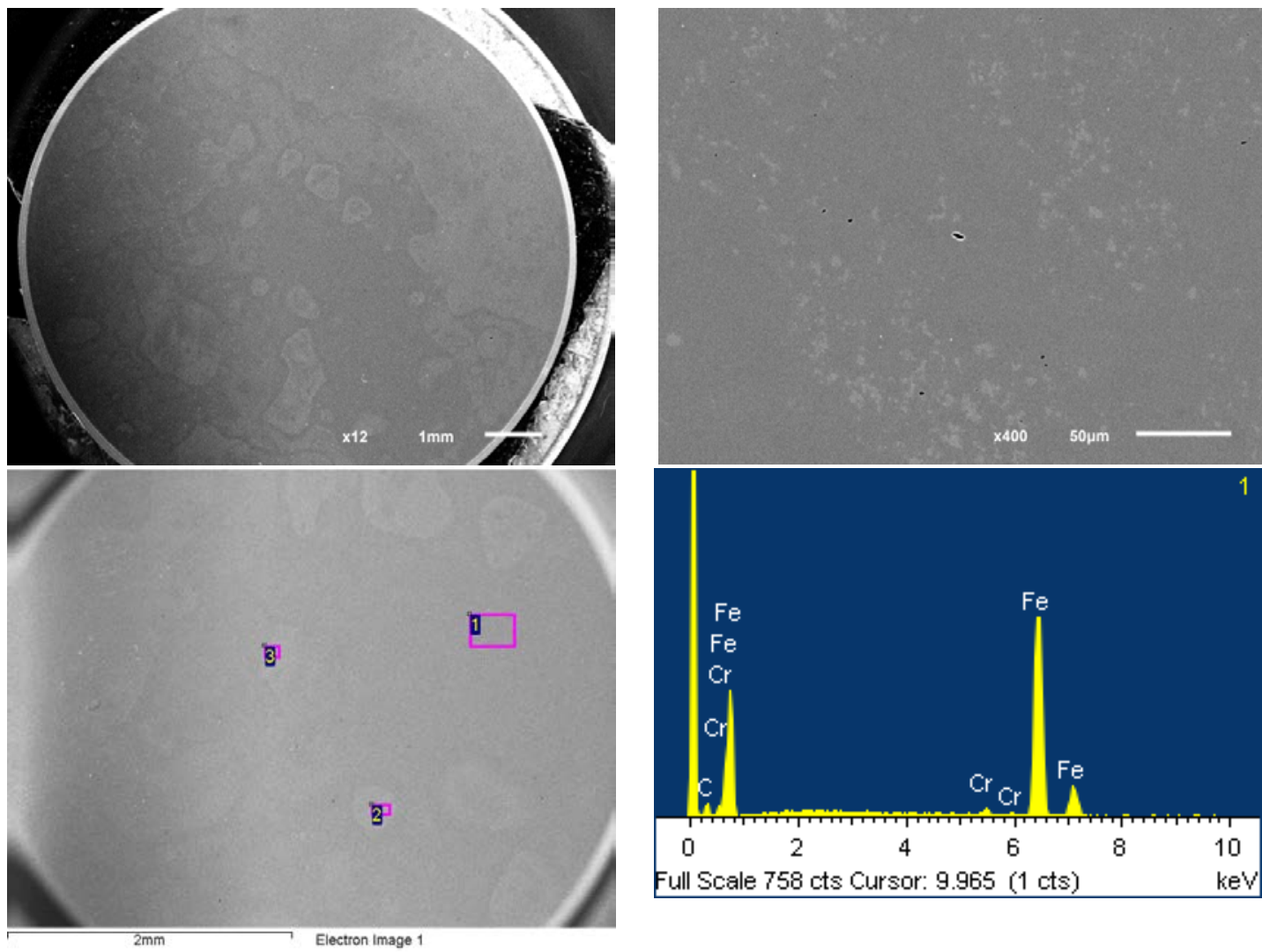

Full Scale 758 cts Cursor: 9.965 (1 cts) kev 

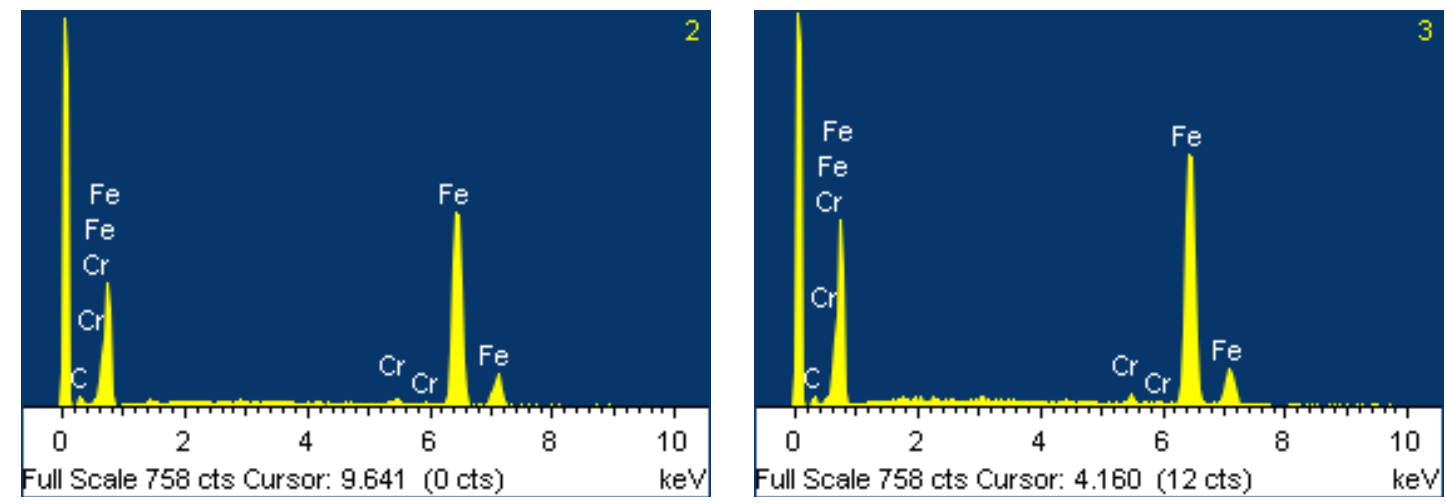

Fig. 6. SEM micrographs (x12 and x400) and EDS spectra of the AISI 52100 steel disc surface wetted with $\left[\mathrm{P}_{66614}\right][\mathrm{BEHP}]$.

On the other hand, the sample wetted with $\left[\mathrm{P}_{66614}\right]\left[\mathrm{NTf}_{2}\right]$ showed presence of corrosion activity on the surface (Fig. 7). In addition, EDS spectra showed other elements (O, S, P, F) than those present in the steel at three different positions of the specimen. These chemical elements present in the ionic liquid reacted with- and damaged the steel surface.
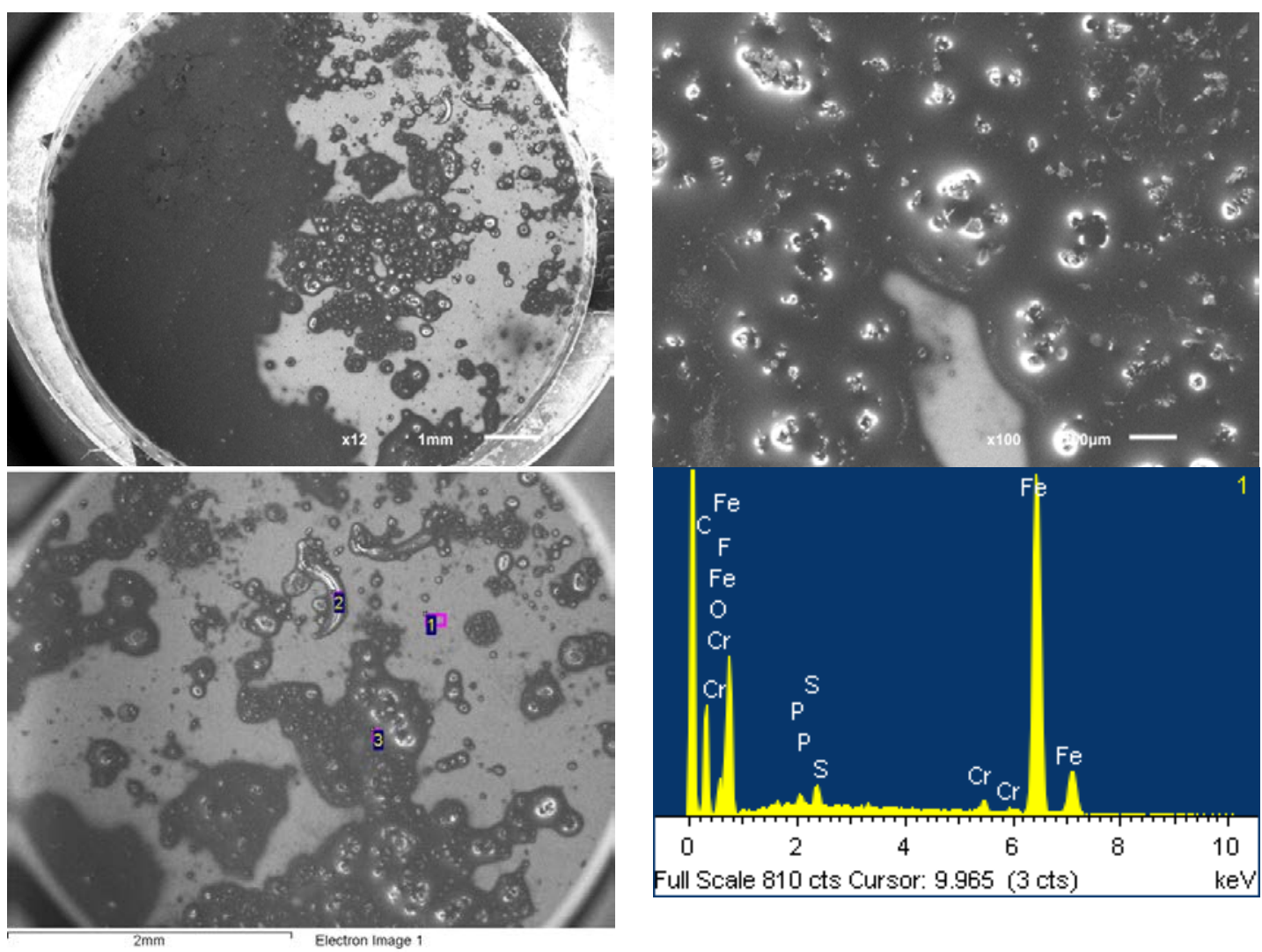

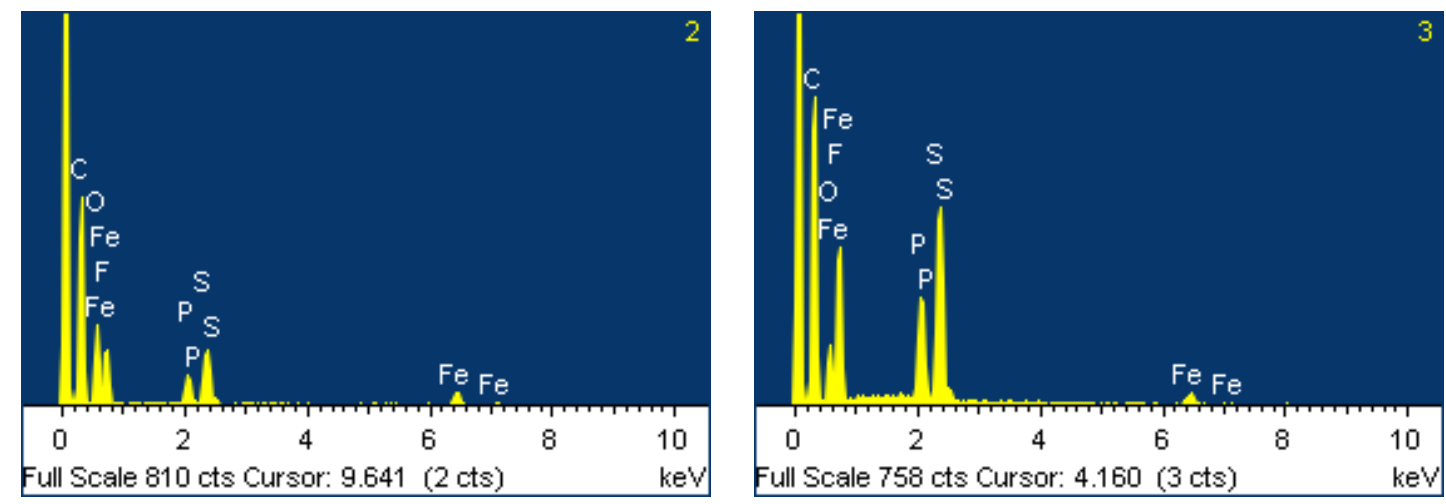

Fig. 7. SEM micrographs (x12 and x100) and EDS spectra of the AISI 52100 steel disc surface wetted with $\left[\mathrm{P}_{66614}\right]\left[\mathrm{NTf}_{2}\right]$

The $\left[\mathrm{P}_{44414}\right][\mathrm{DBS}]$ ionic liquid also provoked corrosion on the surface (Fig. 8) but maybe less aggressive and more homogeneous (covering almost the entire steel specimen) than in the case of the $\left[\mathrm{P}_{66614}\right]\left[\mathrm{NTf}_{2}\right]$, Fig. 7. Besides, EDS spectra (Fig. 8) showed the presence of $\mathrm{O}, \mathrm{S}$ and $\mathrm{P}$ in addition to the typical elements of the steel.
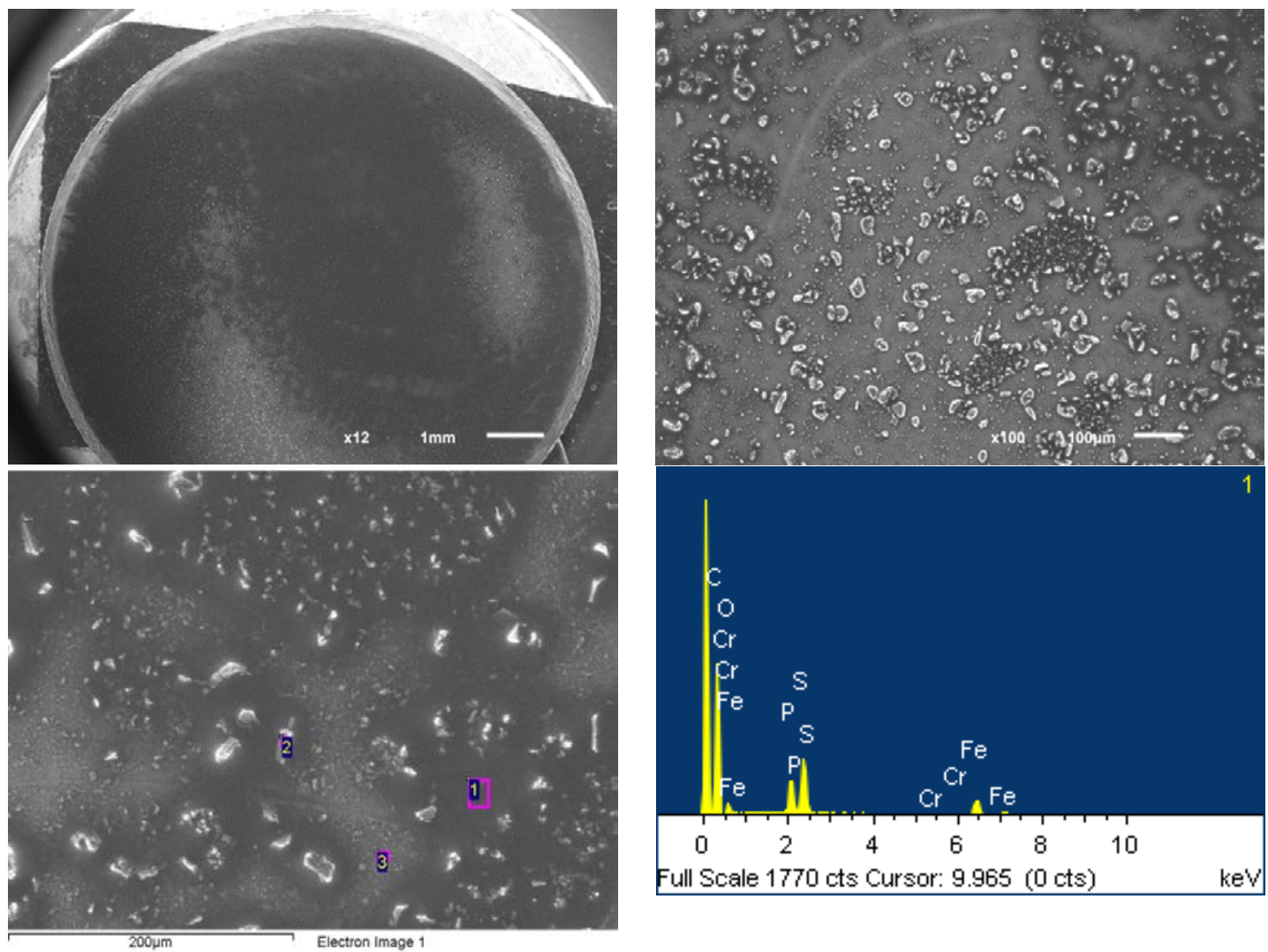

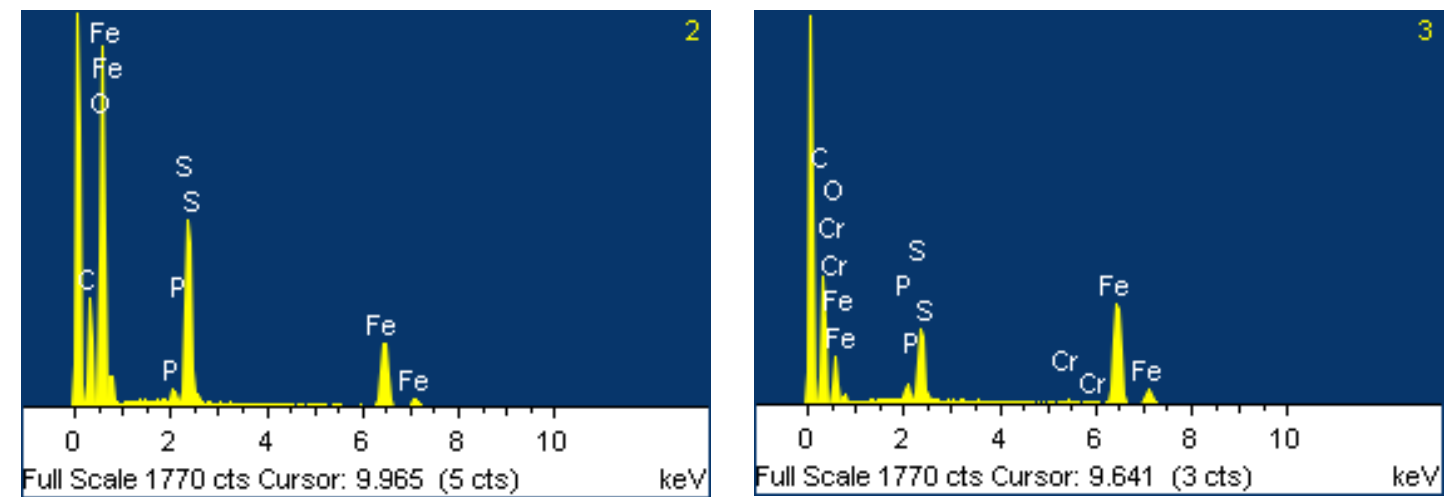

Fig. 8. SEM micrographs (x12 and x100) and EDS spectra of the AISI 52100 steel disc surface wetted with $\left[\mathrm{P}_{44414}\right][\mathrm{DBS}]$.

Finally, the $\left[\mathrm{P}_{4442}\right][\mathrm{DEP}]$ ionic liquid showed the greater corrosion activity (Fig. 9) provoking several cracks on the surface and destroying completely the steel surface. The EDS results indicated a huge presence of phosphorous.
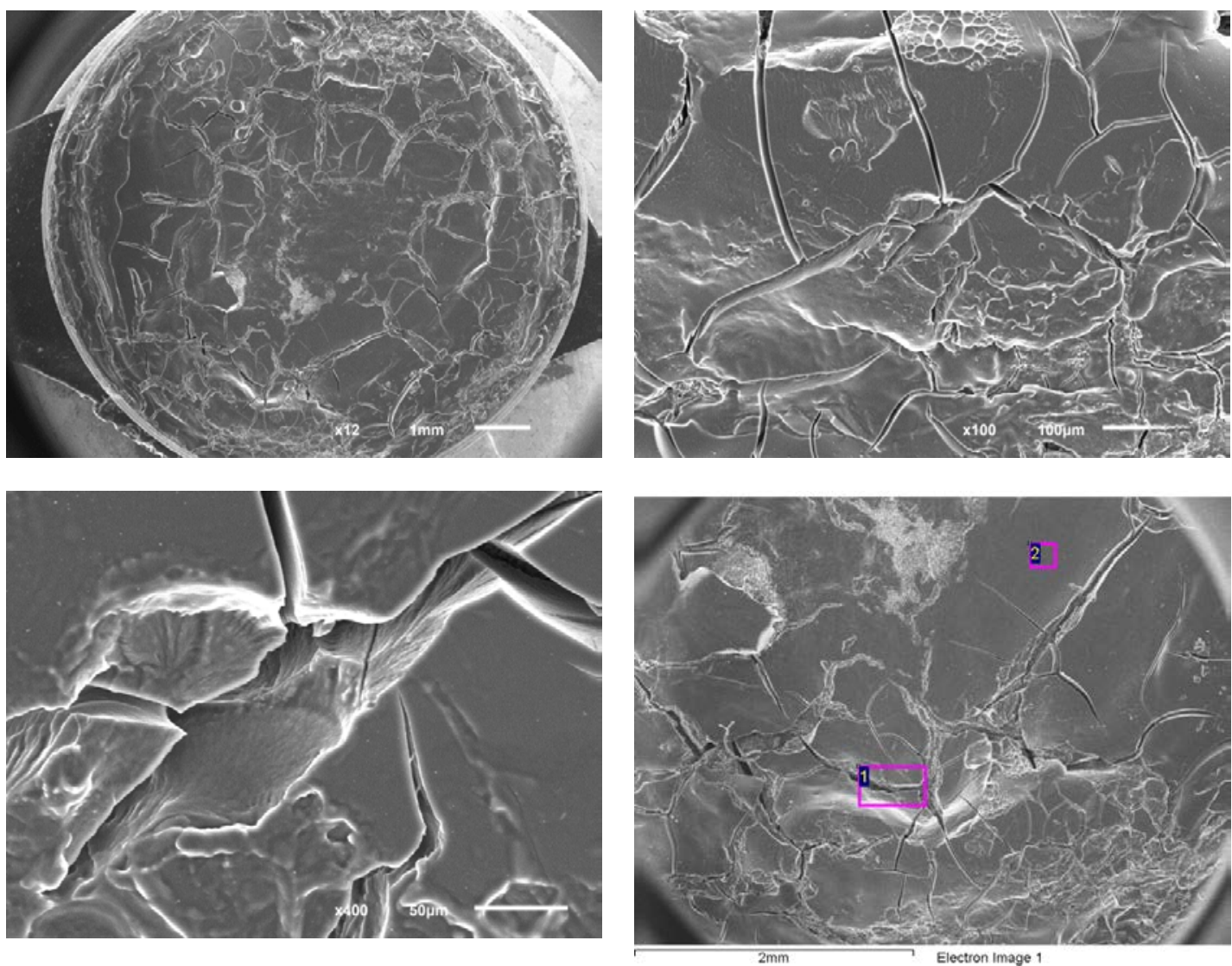

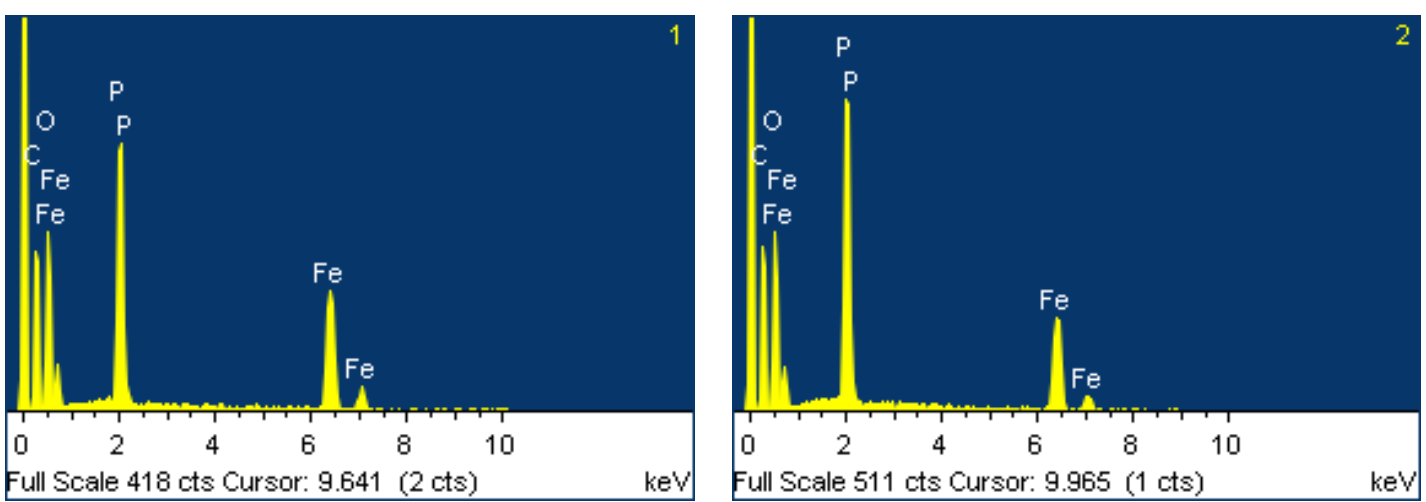

Fig. 9. SEM micrographs (x12, x100, x400) and EDS spectra of the AISI 52100 steel disc surface wetted with $\left[\mathrm{P}_{4442}\right][\mathrm{DEP}]$.

Corrosion phenomenon due to HF generation has already been described for fluorine based-anions such as $\left[\mathrm{BF}_{4}\right]$ and $\left[\mathrm{PF}_{6}\right]$ via hydrolysis [14] or $\left[\mathrm{NTf}_{2}\right]$ via decomposition [50]. On the other hand, the presence of water impurities is another important factor affecting this issue [51]. According to Fig. 3a, [ $\left.\mathrm{P}_{4442}\right][\mathrm{DEP}]$ presented the highest content in water based on its weight loss at $100^{\circ} \mathrm{C}$, what is assumed directly related to the degree of corrosion observed. Furthermore, both ions presented short carbon chains, thus becoming the least hydrophobic ionic liquid. It is, therefore, plausible that $\left[\mathrm{P}_{4442}\right][\mathrm{DEP}]$ absorbs moisture from the atmosphere in a higher degree than the others, increasing the water content and also the corrosion activity. Finally, the sulfonic group present in the $\left[\mathrm{P}_{44414}\right][\mathrm{DBS}]$ ionic liquid may undergo the formation of radicals under certain conditions [52], being these very reactive chemical species a perfect candidate to present corrosion activity.

Despite of the fact that three of the five ionic liquids studied showed clear signs of corrosion, lubrication applications will always be linked to the presence of corrosion inhibitors that minimize this clear negative effect. Comparing the corrosion activity of the $\left[\mathrm{P}_{66614}\right]\left[(\mathrm{iC} 8)_{2} \mathrm{PO}_{2}\right],\left[\mathrm{P}_{66614}\right][\mathrm{BEHP}]$ and $\left[\mathrm{P}_{66614}\right]\left[\mathrm{NTf}_{2}\right]$ ionic liquids (Figs. 5-7), all of them have the same cation and the corrosion of the $\left[\mathrm{P}_{66614}\right]\left[\mathrm{NTf}_{2}\right]$ ionic liquid is related to the presence of the $\left[\mathrm{NTf}_{2}\right]$ anion. However, in previous work [53] the authors proved that the use of other ionic liquids with this anion ([Choline][NTf $\left.f_{2}\right]$ and $[\mathrm{BMP}]\left[\mathrm{NTf}_{2}\right]$ ) did not provoke corrosion on steel surface when the ionic liquid was used as $5 \mathrm{wt} \%$ additive in two fully-formulated wind turbine gearbox oils which had corrosion inhibitors in their formulation.

Ionic liquids are entirely formed by ions which have strong intrinsic electrostatic interactions, putting these substances among the most concentrated electrolytic fluids with many charge carriers per unit volume [54]. The dependence of the conductivity with temperature is shown in Table 5. 
Table 5. Temperature-dependent conductivity of the ionic liquids.

\begin{tabular}{|c|c|c|c|c|c|c|c|}
\hline \multirow{2}{*}{ Ionic Liquids } & \multicolumn{7}{|c|}{ Conductivity ( $\mu \mathrm{S} / \mathrm{cm})$} \\
\hline & $25^{\circ} \mathrm{C}$ & $27^{\circ} \mathrm{C}$ & $30^{\circ} \mathrm{C}$ & $33^{\circ} \mathrm{C}$ & $36^{\circ} \mathrm{C}$ & $39^{\circ} \mathrm{C}$ & $42^{\circ} \mathrm{C}$ \\
\hline$\left[\mathrm{P}_{66614}\right]\left[(\mathrm{iC} 8)_{2} \mathrm{PO}_{2}\right]$ & 0.97 & 1.39 & 2.13 & 2.98 & 3.98 & 5.08 & 6.12 \\
\hline$\left[\mathrm{P}_{66614}\right][\mathrm{BEHP}]$ & 0 & 0.19 & 0.58 & 1 & 1.45 & 2 & 2.59 \\
\hline$\left[\mathrm{P}_{66614}\right]\left[\mathrm{NTf}_{2}\right]$ & 104 & 115.7 & 134.1 & 152.8 & 174.7 & 198.6 & 223.9 \\
\hline$\left[\mathrm{P}_{44414}\right][\mathrm{DBS}]$ & 1.1 & 1.84 & 3.2 & 4.89 & 6.83 & 9.42 & 13.4 \\
\hline$\left[\mathrm{P}_{4442}\right][\mathrm{DEP}]$ & 192.1 & 225.3 & 282.1 & 348 & 414 & 506 & 650 \\
\hline Tap Water & 184.5 & 192.5 & 204.6 & 217.1 & 229.9 & 241.7 & 256.8 \\
\hline
\end{tabular}

The strength of the formed field depends on ions interaction, especially by the size and structure of cation and anion [55]. Electric fields apparently decrease with increasing of cation size, due to the weakening of the electrostatic interaction and the depletion of the number of ions per volume [56]. For an asymmetric anion, such as the one present in $\left[\mathrm{P}_{66614}\right]\left[\mathrm{NTf}_{2}\right]$, the intrinsic electric fields on its subunits are very different, making the net electric field larger than the symmetric ones partially canceled out due to the symmetry [57]. The high viscosity of $\left[\mathrm{P}_{66614}\right]\left[(\mathrm{iC}){ }_{2} \mathrm{PO}_{2}\right],\left[\mathrm{P}_{66614}\right][\mathrm{BEHP}]$ and $\left[\mathrm{P}_{44414}\right][\mathrm{DBS}]$ has a major impact on conductivity because conductivity is inversely proportional to viscosity [54], this fact can be verified in Tables 3 and 4.

\subsection{Tribological tests}

The average friction coefficient of the ionic liquids tested is shown in Fig. 10. It can be observed that the $\left[\mathrm{P}_{4442}\right][\mathrm{DEP}]$ ionic liquid shows the best antifriction behavior with friction coefficient values around 0.06. On the one hand, the $\left[\mathrm{P}_{66614}\right]\left[(\mathrm{iC} 8)_{2} \mathrm{PO}_{2}\right]$ ionic liquid showed the higher friction coefficient. The other three ionic liquids had an intermediate performance. Regarding the wear behavior (Fig. 11), $\left[\mathrm{P}_{66614}\right]\left[\mathrm{NTf}_{2}\right]$ and $\left[\mathrm{P}_{4442}\right][\mathrm{DEP}]$ were the ionic liquids with the lowest values and similar behaviors, while the $\left[\mathrm{P}_{44414}\right][\mathrm{DBS}]$ showed the worst wear value. 


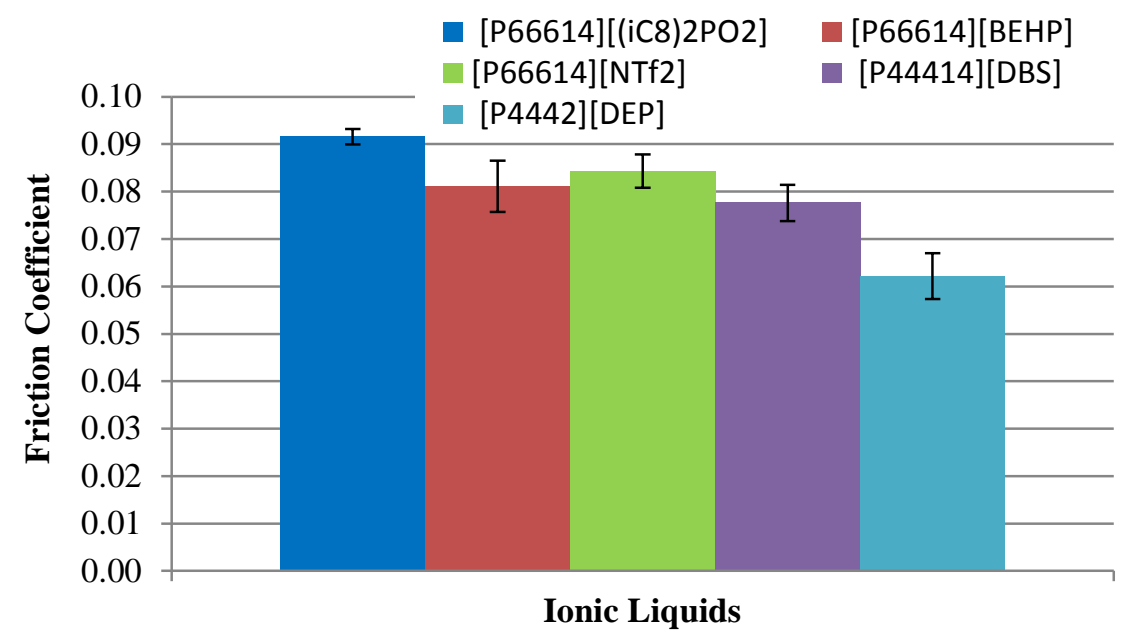

Fig. 10. Mean friction coefficient in the tribological tests.

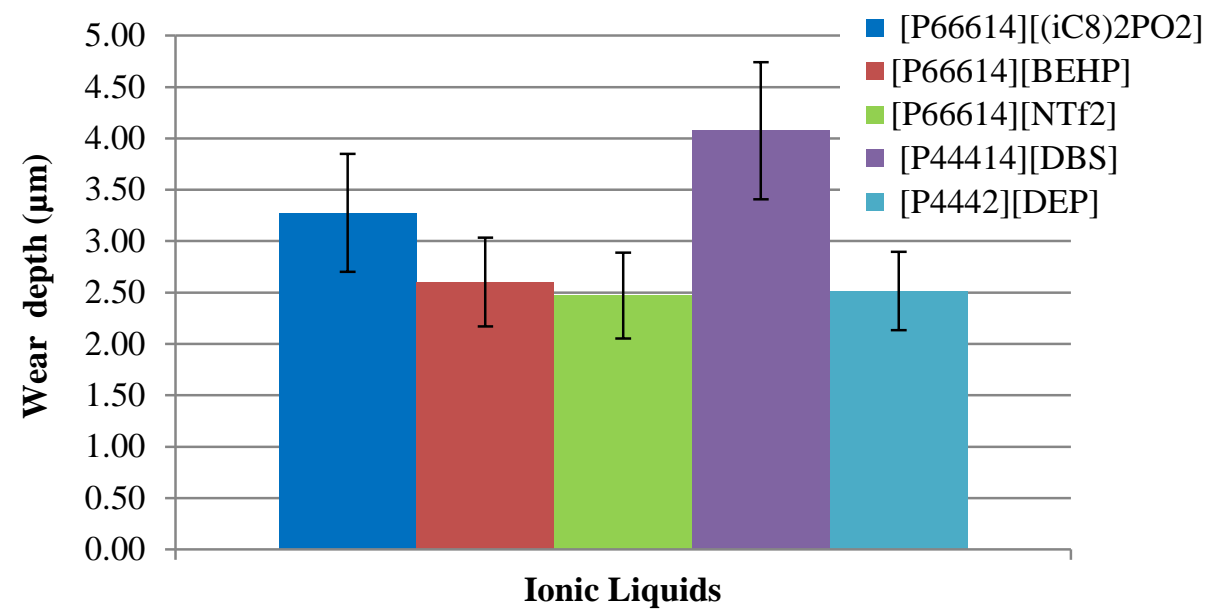

Fig. 11. Wear (mean scar depth) in the tribological tests.

In order to achieve a better comprehension of the friction protection properties of the ionic liquids, representative friction-time records are shown in Fig. 12. It can be observed that the $\left[\mathrm{P}_{4442}\right][\mathrm{DEP}]$ ionic liquid has an initial friction coefficient of about 0.075 , decreasing to an average value of 0.06 after 400 seconds from the beginning of test. This value (0.06) remained approximately stable until the end of the test, showing the lowest friction coefficient. $\left[\mathrm{P}_{4442}\right][\mathrm{DBS}]$ had the second lowest friction coefficient, while $\left[\mathrm{P}_{66614}\right]\left[(\mathrm{iC} 8)_{2} \mathrm{PO}_{2}\right],\left[\mathrm{P}_{66614}\right][\mathrm{BEHP}]$ and $\left[\mathrm{P}_{66614}\right]\left[\mathrm{NTf}_{2}\right]$ showed higher but stable friction coefficient values during the tests. The better friction and wear behavior of $\left[\mathrm{P}_{4442}\right][\mathrm{DEP}]$ seem not to be related to its viscosity, thermal stability and corrosion properties. Thermal stability and viscosity values of $\left[\mathrm{P}_{4442}\right][\mathrm{DEP}]$ are among the lowest ones but the fact that the tribological tests were made at room 
temperature and with a small quantity of ionic liquid suggest that its tribological behavior are close related to chemical interaction with surface. On one hand, the corrosion activity of the ionic liquids was tested in a 20-days room temperature test, which is quite different from the 60-minutes tribological tests, and while the $\left[\mathrm{P}_{4442}\right][\mathrm{DEP}]$ showed a long-term corrosion activity, it also had the best tribological behavior. On the other hand, the $\left[\mathrm{P}_{66614}\right]\left[(\mathrm{iC} 8)_{2} \mathrm{PO}_{2}\right]$ did not show corrosion activity but presented the higher friction coefficient and the second larger wear results confirming that chemical interaction with surface during friction and wear tests which lead to tribofilms formation is the mechanism that control the tribological results.

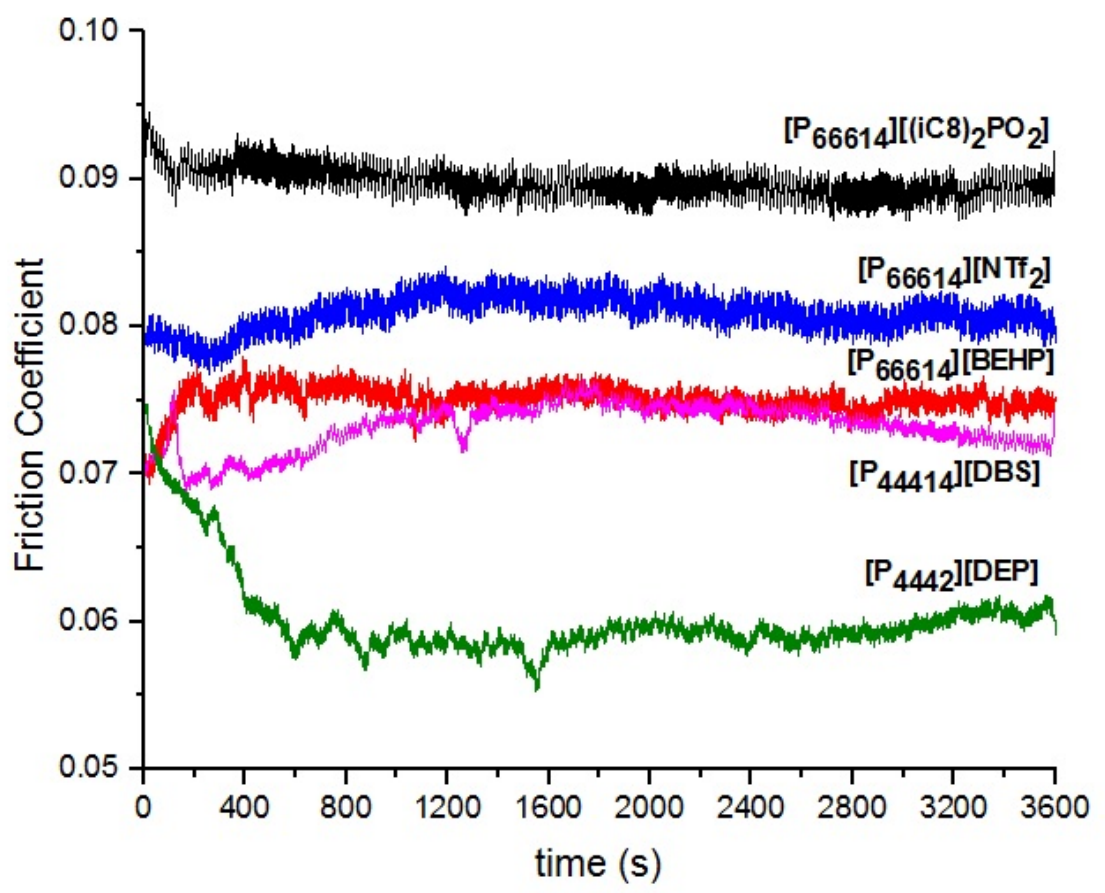

Fig. 12. Evolution of friction coefficient during the tribological tests.

\subsection{Surface characterization}

The SEM micrographs (Fig. 13) showed the correspondence with the tribological behavior of the ionic liquids, where $\left[\mathrm{P}_{66614}\right][\mathrm{BEHP}]$ and $\left[\mathrm{P}_{4442}\right][\mathrm{DEP}]$ had the best friction and antiwear behavior. However, it is important to take into account that a longer interaction of steel surface with the $\left[\mathrm{P}_{4442}\right][\mathrm{DEP}]$ ionic liquid present problems from the corrosion point of view (Fig. 9). In all cases, the EDS analysis mainly showed the elements present in the steel disc, so the XPS analysis will can reveal the nature of the tribofilm formed by the IL-surface chemical interaction. 


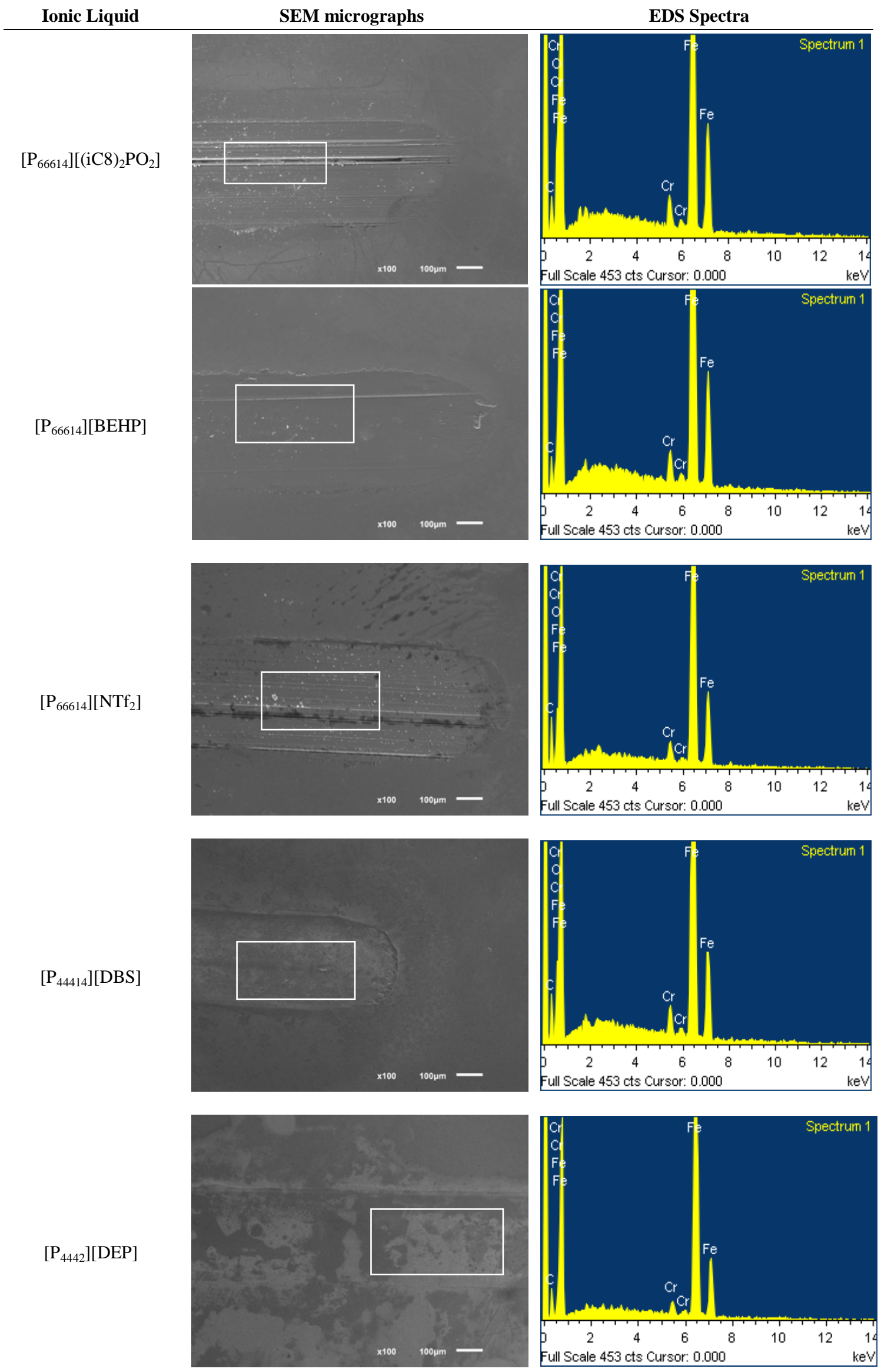


Fig. 13. SEM micrographs (x100) and EDS spectra (taken from the marked zone) of wear surfaces after the tribological tests.

XPS analysis was carried out performing high-resolution spectra after different etching times for several elements, depending on the chemical composition of the ionic liquid. The sputtering ion beam current was $50 \mu \mathrm{A}$, so assuming material used as iron with atom radius of $1.26 \AA$ and sputtering yield of 2.751 [58], the sputtering rate can be estimated in $0.12 \mathrm{~nm} / \mathrm{s}$. Phosphorus was evaluated in every sample, as this is a common element for all of them. It is interesting to state that $\left[\mathrm{P}_{66614}\right]\left[(\mathrm{iC} 8)_{2} \mathrm{PO}_{2}\right],\left[\mathrm{P}_{66614}\right]\left[\mathrm{NTf}_{2}\right]$ and $\left[\mathrm{P}_{44414}\right][\mathrm{DBS}]$ presented only a P2p doublet independently of the depth, whereas $\left[\mathrm{P}_{66614}\right][\mathrm{BEHP}]$ and $\left[\mathrm{P}_{4442}\right][\mathrm{DEP}]$ showed two doublets. $\left[\mathrm{P}_{66614}\right]\left[(\mathrm{iC} 8)_{2} \mathrm{PO}_{2}\right]$ presents a peak near $134 \mathrm{eV}$, probably from $\mathrm{FePO}_{4}$ [9,59], which decreases with depth until reaching a plateau after $\sim 7 \mathrm{~nm}$ sputtering (Fig. 14a). Sample $\left[\mathrm{P}_{44414}\right][\mathrm{DBS}]$ show a constant profile with depth. Samples $\left[\mathrm{P}_{66614}\right][\mathrm{BEHP}]$ and $\left[\mathrm{P}_{4442}\right][\mathrm{DEP}]$, however, show two doublets. A first one near $134 \mathrm{eV}$ which can be assumed as $\mathrm{FePO}_{4}$, which has been described as a friction product in previous works [60] and a second one at ca. $131 \mathrm{eV}$. This low energy suggests a C-P bond [61] which is present in any of the used cations. However, without further evidence, this energy cannot be assigned confidently to the cations. It is however very remarkable that the two samples with better tribological performance show a second doublet which is not present in the others.
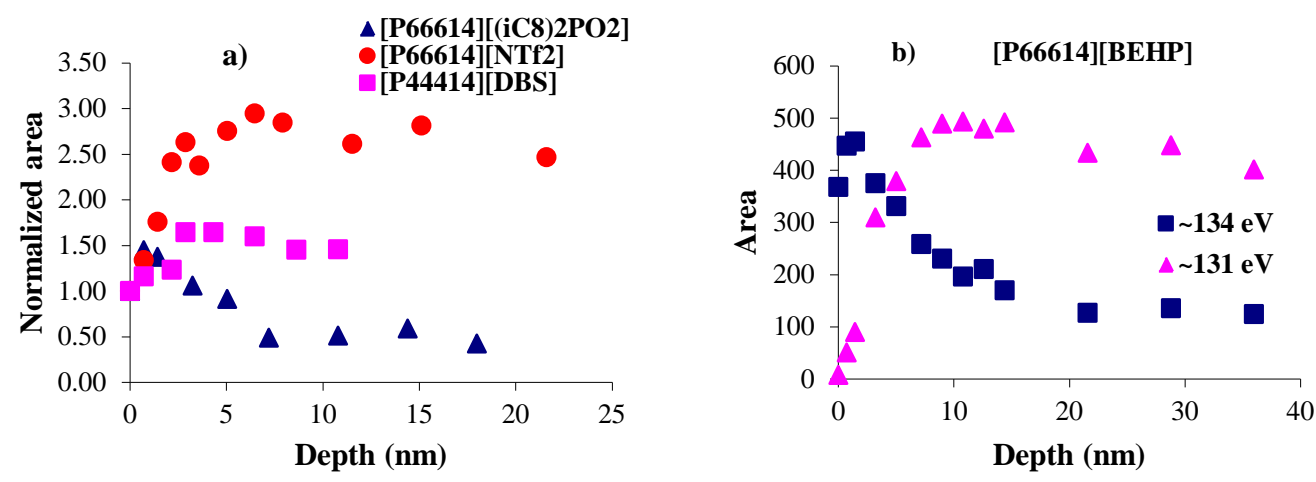


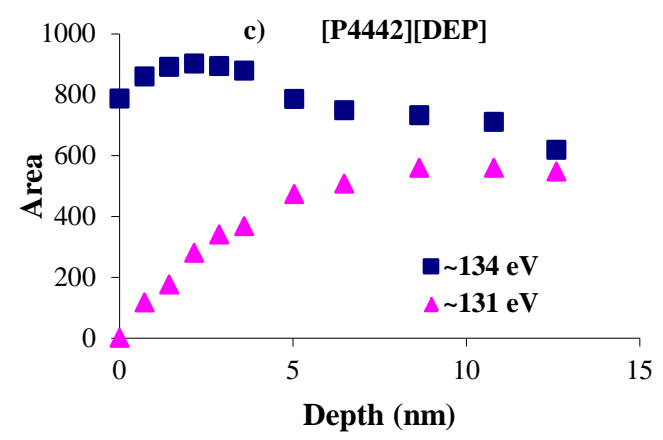

Fig. 14. Behaviour of P2p band in the wear scar of samples lubricated with different ionic liquids. Area is measured in arbitrary units; normalized area is used when comparing different bands in the same sample and the normalization factor is the area of the peak at $\mathrm{t}=0$.

As discussed previously, $\left[\mathrm{P}_{66614}\right]\left[\mathrm{NTf}_{2}\right]$ damaged seriously the surface. This sample shows a sharp increase in phosphorus content in the first $2 \mathrm{~nm}$ keeping constant after that (Fig. 15a). The signal of F1s increases initially (up to the first $6 \mathrm{~nm}$ ), probably due to the presence of residual $\mathrm{NTf}_{2}$ which was not completely removed, and then decreases. The idea of residual $\left[\mathrm{NTf}_{2}\right]$ anion in the initial $6 \mathrm{~nm}$ is supported as well by the presence of sulphur within the first $6 \mathrm{~nm}$ depth, which disappears completely after that. The binding energy of F1s in the surface is $689.5 \mathrm{eV}$, quite close to $689.0 \mathrm{eV}$ as proposed by Bovio et al. [62] for $\left[\mathrm{NTf}_{2}\right]$ anion. This binding energy shifts to lower values as we go deeper into the sample until reaching $\sim 688.2 \mathrm{eV}$, suggesting that fluorine trends to interact with an element with a lower electronegativity than C. This behavior is summarized in Fig. 15b. On the other hand, sulphur did not show the same stability in the surface, as it almost disappeared after $3.5 \mathrm{~nm}$ (Fig. 15c).
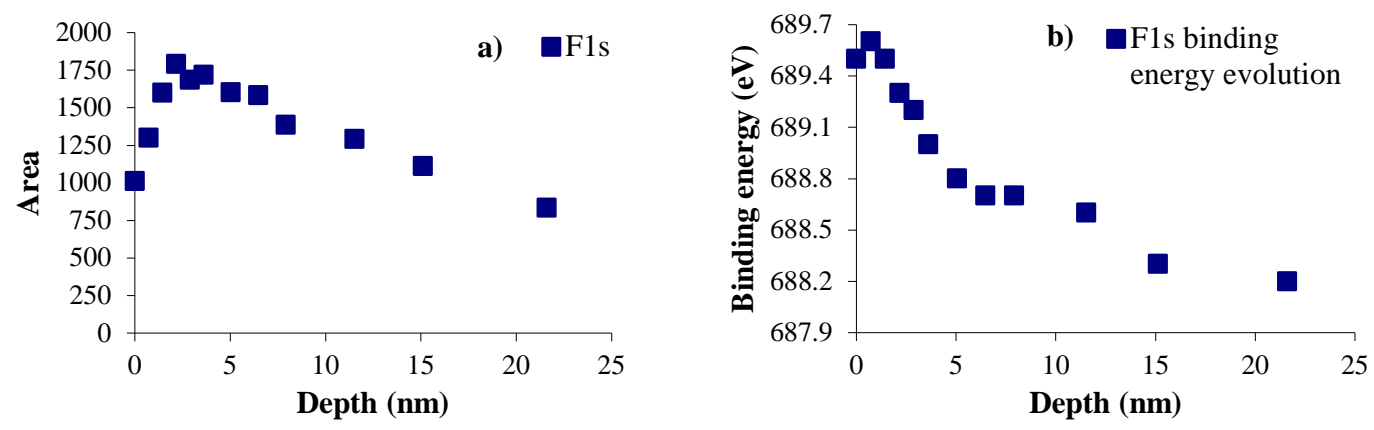


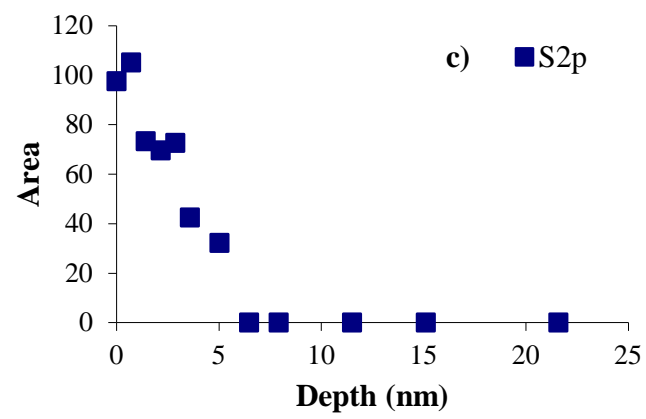

Fig. 15. Behaviour of the F1s and S2p signal in the wear scar of sample lubricated with $\left[\mathrm{P}_{66614}\right]\left[\mathrm{NTf}_{2}\right]$.

The behavior of sulphur is different in the case of $\left[\mathrm{P}_{44414}\right][\mathrm{DBS}]$. The sulphur in the surface appears as a doublet at ca. $168 \mathrm{eV}$. However, this signal decreases with depth while a new one at ca. $163.2 \mathrm{eV}$ grows (Fig. 16). It is not easy to identify the chemical nature of both signals, but high values are usually related to high oxidation degrees like sulphates or sulphonium and lower ones are related to low oxidation degrees (e.g. sulphide) [61].

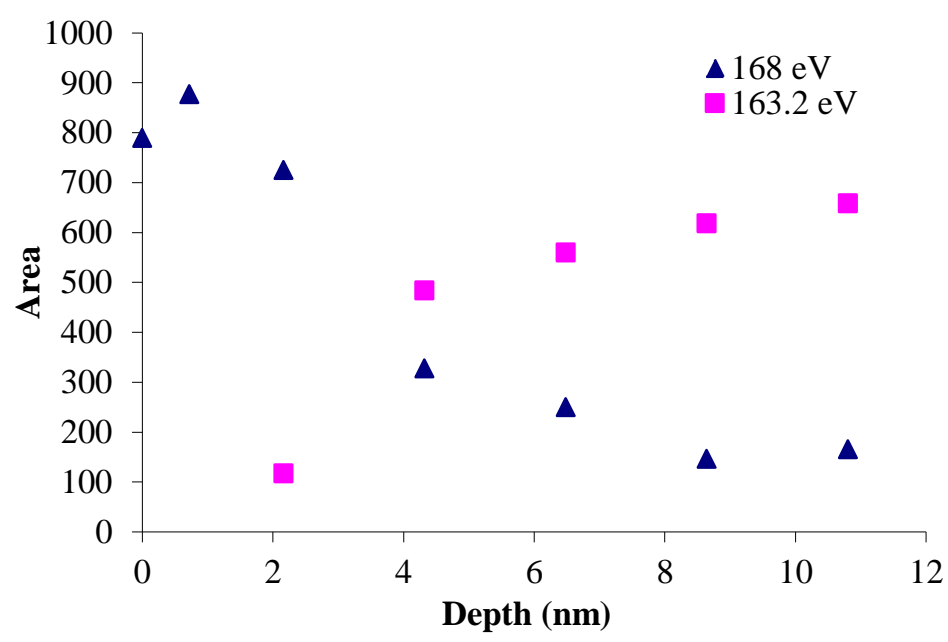

Fig. 16. S2p signal in the wear scar of sample lubricated with $\left[\mathrm{P}_{44414}\right][\mathrm{DBS}]$.

\section{Conclusions}

Five phosphonium cation-based ionic liquids were studied from physicochemical and tribological points of view and the main conclusions that can be drawn are:

- The size, symmetry and structure of both ions have strong influence on viscosity, thermal stability, conductivity and corrosion. 
- The $\left[\mathrm{P}_{66614}\right]\left[\mathrm{NTf}_{2}\right],\left[\mathrm{P}_{44414}\right][\mathrm{DBS}]$, and $\left[\mathrm{P}_{4442}\right][\mathrm{DEP}]$ ionic liquids showed corrosion activity, likely related to water presence as impurity, radical formation and HF generation.

- In general all ionic liquids showed thermal stability at least until $240^{\circ} \mathrm{C}$ and, as expected, higher values under inert atmosphere. $\left[\mathrm{P}_{66614}\right][\mathrm{BEHP}]$ and $\left[\mathrm{P}_{4442}\right][\mathrm{DEP}]$ showed lowest degradation temperatures and two degradation steps probably related to the influence of a more reactive phosphate type anion that controls the thermal stability and the degradation behavior. The more reactive character of these anions contributed to the best tribological behaviour shown by these ionic liquids.

- The XPS results confirmed that the best tribological performance of $\left[\mathrm{P}_{66614}\right][\mathrm{BEHP}]$ and $\left[\mathrm{P}_{4442}\right][\mathrm{DEP}]$ are closely related to the presence of two phosphor-containing species in the wear scar.

- The higher conductivity values of the $\left[\mathrm{P}_{66614}\right]\left[\mathrm{NTf}_{2}\right]$ and $\left[\mathrm{P}_{4442}\right][\mathrm{DEP}]$ ionic liquids are very interesting if a conductive lubricant want to be formulated, for example ionic liquid-based conductive grease. Taking into account the higher conductivity and tribological behavior, the $\left[\mathrm{P}_{4442}\right][\mathrm{DEP}]$ ionic liquid would be the best candidate to be included in that formulation but adding corrosion inhibitors.

\section{Acknowledgements}

The authors would like to thank to the Ministry of Economy and Competitiveness (Spain) and FICYT (Foundation for the Promotion in Asturias of the Applied Scientific Research and Technology) for supporting the research projects STARLUBE (DPI2013-48348-C2-1-R) and GRUPIN14-023, respectively, under the framework this research was developed. The Units of Photoelectron, UV-vis, FTIR spectroscopy and SEM-EDS from the Scientific-Technical Services at the University of Oviedo are also acknowledged.

\section{References}

[1] Chum HL, Koch VR, Miller LL, Osteryoung RA. Electrochemical scrutiny of organometallic iron complexes and hexamethylbenzene in a room temperature molten salt. J Am Chem Soc 1975; 97 (11): 3264. 
[2] Wilkes JS, Levisky JA, Wilson RA, Hussey CL. Dialkylimidazolium chloroaluminate melts: a new class of room-temperature ionic liquids for electrochemistry, spectroscopy and synthesis. Inorg Chem 1982;21 (3): 1263-1264.

[3] Minami I. Ionic liquids in tribology. Molecules 2009;14:2286-305. doi:10.3390/molecules14062286.

[4] Ye C, Liu W, Chen Y, Yu L. Room-temperature ionic liquids: a novel versatile lubricant. Chem Commun (Camb) 2001:2244-5. doi:10.1039/B106935G.

[5] Somers A, Howlett P, MacFarlane D, Forsyth M. A Review of Ionic Liquid Lubricants. Lubricants 2013;1:3-21. doi:10.3390/lubricants1010003.

[6] Bermúdez MD, Jiménez AE, Sanes J, Carrión FJ. Ionic liquids as advanced lubricant fluids. Molecules 2009;14:2888-908. doi:10.3390/molecules14082888.

[7] Blanco D, Battez AH, Viesca JL, González R, Fernández-González A. Lubrication of CrN coating with ethyl-dimethyl-2-methoxyethylammonium tris(pentafluoroethyl)trifluorophosphate ionic liquid as additive to PAO 6. Tribol Lett 2011;41:295-302. doi:10.1007/s11249-010-9714-1.

[8] Blanco D, González R, Hernández Battez A, Viesca JL, Fernández-Gonzlez A. Use of ethyldimethyl-2-methoxyethylammonium tris(pentafluoroethyl) trifluorophosphate as base oil additive in the lubrication of TiN PVD coating. Tribol Int 2011;44:645-50. doi:10.1016/j.triboint.2011.01.004.

[9] Viesca JL, García A, Hernández Battez A, González R, Monge R, Fernández-González A, et al. FAP- anion ionic liquids used in the lubrication of a steel-steel contact. Tribol Lett 2013;52:431-7. doi:10.1007/s11249-013-0226-7.

[10] Viesca JL, Battez AH, González R, Reddyhoff T, Pérez AT, Spikes HA. Assessing boundary film formation of lubricant additivised with 1-hexyl-3-methylimidazolium tetrafluoroborate using ECR as qualitative indicator. Wear 2010;269:112-7. doi:10.1016/j.wear.2010.03.014.

[11] Wang H, Lu Q, Ye C, Liu W, Cui Z. Friction and wear behaviors of ionic liquid of alkylimidazolium hexafluorophosphates as lubricants for steel/steel contact. Wear 2004;256:44-8. doi:10.1016/S0043-1648(03)00255-2.

[12] Mu Z, Zhou F, Zhang S, Liang Y, Liu W. Effect of the functional groups in ionic liquid molecules on the friction and wear behavior of aluminum alloy in lubricated aluminum-on-steel contact. Tribol Int 2005;38:725-31. doi:10.1016/j.triboint.2004.10.003. 
[13] Phillips BS, Zabinski JS. Ionic liquid lubrication effects on ceramics in a water environment. Tribol Lett 2004;17:533-41. doi:10.1023/B:TRIL.0000044501.64351.68.

[14] Liu W, Ye C, Gong Q, Wang H, Wang P. Tribological performance of room-temperature ionic liquids as lubricant. Tribol Lett 2002;13:81-5. doi:10.1023/A:1020148514877.

[15] Chen YM, Zeng ZX, Yang SR, Zhang JY. The tribological performance of BCN films under ionic liquids lubrication. Diam Relat Mater 2009;18:20-6. doi:10.1016/j.diamond.2008.07.023.

[16] Battez AH, González R, Viesca JL, Blanco D, Asedegbega E, Osorio A. Tribological behaviour of two imidazolium ionic liquids as lubricant additives for steel/steel contacts. Wear 2009;266:12248. doi:10.1016/j.wear.2009.03.043.

[17] Torimoto T, Tsuda T, Okazaki KI, Kuwabata S. New frontiers in materials science opened by ionic liquids. Adv Mater 2010;22:1196-221. doi:10.1002/adma.200902184.

[18] Barnhill WC, Qu J, Luo H, Meyer HM, Ma C, Chi M, et al. Phosphonium-Organophosphate Ionic Liquids as Lubricant Additives : Effects of Cation Structure on Physicochemical and Tribological Characteristics. ACS Appl Mater Interfaces 2014;6:22585-93.

[19] Zhou Y, Graham TW, Luo H, Leonard DN, Qu J. Ionic Liquids Composed of Phosphonium Cations and Organophosphate, Carboxylate, and Sulfonate Anions as Lubricant Antiwear Additives. Langmuir 2014.

[20] Otero I, López ER, Reichelt M, Villanueva M, Salgado J, Fernández J. Ionic liquids based on phosphonium cations as neat lubricants or lubricant additives for a steel/steel contact. ACS Appl Mater Interfaces 2014;6:13115-28. doi:10.1021/am502980m.

[21] Jiménez AE, Bermúdez MD. Imidazolium ionic liquids as additives of the synthetic ester propylene glycol dioleate in aluminium-steel lubrication. Wear 2008;265:787-98. doi:10.1016/j.wear.2008.01.009.

[22] Otero I, López ER, Reichelt M, Fernández J. Friction and anti-wear properties of two tris(pentafluoroethyl) trifluorophosphate ionic liquids as neat lubricants. Tribol Int 2014;70:104-11. doi:10.1016/j.triboint.2013.10.002.

[23] Palacio M, Bhushan B. A review of ionic liquids for green molecular lubrication in nanotechnology. Tribol Lett 2010;40:247-68. doi:10.1007/s11249-010-9671-8.

[24] González R, Hernández Battez A., Blanco D, Viesca JL, Fernández-González A. Lubrication of TiN, CrN and DLC PVD coatings with 1-butyl-1- methylpyrrolidinium 
tris(pentafluoroethyl)trifluorophosphate. Tribol Lett 2010;40:269-77. doi:10.1007/s11249-0109674-5.

[25] Qu J, Truhan JJ, Dai S, Luo H, Blau PJ. Ionic liquids with ammonium cations as lubricants or additives. Tribol Lett 2006;22:207-14. doi:10.1007/s11249-006-9081-0.

[26] Jiménez a. E, Bermúdez MD, Iglesias P, Carrión FJ, Martínez-Nicolás G. 1-N-alkyl -3methylimidazolium ionic liquids as neat lubricants and lubricant additives in steel-aluminium contacts. Wear 2006;260:766-82. doi:10.1016/j.wear.2005.04.016.

[27] Mahrova M, Pagano F, Pejakovic V, Valea A., Kalin M, Igartua A, et al. Pyridinium based dicationic ionic liquids as base lubricants or lubricant additives. Tribol Int 2015;82:245-54. doi:10.1016/j.triboint.2014.10.018.

[28] García A., González R, Hernández Battez A., Viesca JL, Monge R, Fernández-González A., et al. Ionic liquids as a neat lubricant applied to steel-steel contacts. Tribol Int 2014;72:42-50. doi:10.1016/j.triboint.2013.12.007.

[29] Qu J, Blau PJ, Dai S, Luo H, Meyer HM. Ionic Liquids as Novel Lubricants and Additives for Diesel Engine Applications. Tribol Lett 2009;35:181-9. doi:10.1007/s11249-009-9447-1.

[30] Zhang S, Hu L, Qiao D, Feng D, Wang H. Vacuum tribological performance of phosphoniumbased ionic liquids as lubricants and lubricant additives of multialkylated cyclopentanes. Tribol Int 2013;66:289-95. doi:10.1016/j.triboint.2013.06.012.

[31] Nainaparampil JJ, Eapen KC, Sanders JH, Voevodin A a. Ionic-liquid lubrication of sliding MEMS contacts: Comparison of AFM liquid cell and device-level tests. J Microelectromechanical Syst 2007;16:836-43. doi:10.1109/JMEMS.2007.901628.

[32] Fraser KJ, MacFarlane DR. Phosphonium-based ionic liquids: An overview. Aust J Chem 2009;62:309-21. doi:10.1071/CH08558.

[33] Minami I, Inada T, Sasaki R, Nanao H. Tribo-Chemistry of Phosphonium-Derived Ionic Liquids. Tribol Lett 2010;40:225-35. doi:10.1007/s11249-010-9626-0.

[34] Liu X, Zhou F, Liang Y, Liu W. Tribological performance of phosphonium based ionic liquids for an aluminum-on-steel system and opinions on lubrication mechanism. Wear 2006;261:1174-9. doi:10.1016/j.wear.2006.03.018. 
[35] Minami I, Kita M, Kubo T, Nanao H, Mori S. The tribological properties of ionic liquids composed of trifluorotris(pentafluoroethyl) phosphate as a hydrophobic anion. Tribol Lett 2008;30:215-23. doi:10.1007/s11249-008-9329-y.

[36] Somers AE, Howlett PC, Sun J, MacFarlane DR, Forsyth M. In Phosphonium Ionic Liquids as Lubricants for Aluminium-Steel, Tribology \& design: Proceedings of the 3rd International Conference on Tribology in Environmental Design 2010, Algarve, Portugal, WIT: 2010; pp 273-284.

[37] Weng LJ, Liu XQ, Liang YM, Xue QJ. Effect of tetraalkylphosphonium based ionic liquids as lubricants on the tribological performance of a steel-on-steel system. Tribol Lett 2007;26:11-7. doi:10.1007/s11249-006-9175-8.

[38] Somers AE, Khemchandani B, Howlett PC, Sun J, Macfarlane DR, Forsyth M. Ionic liquids as antiwear additives in base oils: Influence of structure on miscibility and antiwear performance for steel on aluminum. ACS Appl Mater Interfaces 2013;5:11544-53. doi:10.1021/am4037614.

[39] Somers AE, Biddulph SM, Howlett PC, Sun J, MacFarlane DR, Forsyth M. A comparison of phosphorus and fluorine containing IL lubricants for steel on aluminium. Phys Chem Chem Phys 2012;14:8224. doi:10.1039/c2cp40736a.

[40] Shirley DA. High-resolution X-ray photoemission spectrum of the valence bands of gold. Phys Rev B 5 1972;4709-4714.

[41] Åberg ER, Gustavsson AGT. Design and evaluation of modified simplex methods, Anal Chim Acta 1982;144 39-53

[42] Socrates G. Infrared and raman characteristic group frequencies, tables and charts. 3rd edition, Ed. Wiley 2001.

[43] Spectral database for Organic Compounds SDBS, http://sdbs.db.aist.go.jp/sdbs/cgibin/cre_index.cgi, last access July 10th, 2015.

[44] Kilaru P, Baker GA, Scovazzo P. Density and surface tension measurements of imidazolium-, quaternary phosphonium-, and ammonium-based room-temperature ionic liquids: Data and correlations. J Chem Eng Data 2007;52:2306-14. doi:10.1021/je7003098.

[45] Zhang X, Huo F, Liu X, Dong K, He H, Yao X, et al. Influence of Microstructure and Interaction on Viscosity of Ionic Liquids. Ind Eng Chem Res 2015;54:3505-14. doi:10.1021/acs.iecr.5b00415. 
[46] Ferreira AF, Simões PN, Ferreira AGM. Quaternary phosphonium-based ionic liquids: Thermal stability and heat capacity of the liquid phase. J Chem Thermodyn 2012;45:16-27. doi:10.1016/j.jct.2011.08.019.

[47] Salgado J, Villanueva M, Parajó JJ, Fernández J. Long-term thermal stability of five imidazolium ionic liquids. J Chem Thermodyn 2013;65:184-90. doi:10.1016/j.jct.2013.05.049.

[48] Shirota H, Mandai T, Fukazawa H, Kato T. Comparison between dicationic and monocationic ionic liquids: Liquid density, thermal properties, surface tension, and shear viscosity. J Chem Eng Data 2011;56:2453-9. doi:10.1021/je2000183.

[49] Green MD, Schreiner C, Long TE. Thermal , Rheological , and Ion-Transport Properties of Phosphonium-Based Ionic Liquids. J Phys Chem 2011:13829-35.

[50] Keating MY, Gao F, Ramsey JB. TGA-MS study of the decomposition of phosphorus-containing ionic liquids trihexyl(tetradecyl)phosphonium decanoate and trihexyltetradecylphosphonium bis[(trifluoromethyl)sulfonyl] amide. J Therm Anal Calorim 2011;106:207-11. doi:10.1007/s10973-011-1528-3.

[51] Uerdingen, M., Treber, C., Balser, M., Schmitt, G., Werner, C. Corrosion behavior of ionic liquids. Green Chem. 2005, 7, 321.

[52] Griesbeck, A., Oelgemöller, M., Ghetti, F. CRC Handbook of Organic Photochemistry and Photobiology, Volume 1, chapter 17. CRC Group, Taylor and Francis group, 3rd edition, Boca Ratón, 2012. ISBN 978-1-4398-1181-8.

[53] Monge R, González R, Hernández Battez A, Fernández-González A, Viesca JL, García A, et al. Ionic liquids as an additive in fully formulated wind turbine gearbox oils. Wear 2015;328-329:5063. doi:10.1016/j.wear.2015.01.041.

[54] Hapiot P, Lagrost C. Electrochemical reactivity in room-temperature ionic liquids. Chem Rev 2008;108:2238-64. doi:10.1021/cr0680686.

[55] Zhang S, Shi R, Ma X, Lu L, He Y, Zhang X, et al. Intrinsic electric fields in ionic liquids determined by vibrational stark effect spectroscopy and molecular dynamics simulation. Chem A Eur J 2012;18:11904-8. doi:10.1002/chem.201201257.

[56] Fan X, Wang L. Highly conductive ionic liquids toward high-performance space-lubricating greases. ACS Appl Mater Interfaces 2014;6:14660-71. doi:10.1021/am503941e. 
[57] Taniki R, Matsumoto K, Hagiwara R. Trialkylsulfonium Fluorohydrogenate Giving the Highest Conductivity in Room Temperature Ionic Liquids. Electrochem Solid-State Lett 2012;15:F13. doi:10.1149/2.025204esl.

[58] http://www.iap.tuwien.ac.at/www/surface/sputteryield, last visited October 16th, 2015

[59] Barbaux Y, Dekiouk M, Le Maguer D, Gengembre L, Huchette D, Grimblot J. Bulk and surface analysis of a Fe-P-O oxydehydrogenation catalyst. Appl Catal A 1992; 90:51-60. doi: 10.1016/0926-860X(92)80247-A

[60] Fan X, Xia Y, Wang L. Tribological properties of conductive lubricating greases. Friction 2014;2:343-53. doi:10.1007/s40544-014-0062-2.

[61] NIST Standard Reference Database, http:// http://srdata.nist.gov/xps/Default.aspx, last updated September 15, 2012, last accessed October $16^{\text {th }}, 2015$.

[62] Bovio S., Podesta A., Lenardi C., Milani P. Evidence of extended solid like layering in [Bmim][NTf 2 ionic liquid thin films at room-temperature. J. Phys. Chem. B 2009; 113:6600-3. doi: 10.1021/jp9022234 